Araștırma ve Geliștirme Dergisi

International Journal of

Engineering Research and

Development
UMAGD, (2021) 13(2), 462-477.

10.29137/umagd.874818

Cilt/Volume:13 Sayı/Issue:2 Haziran/June 2021

Araştırma Makalesi / Research Article

\title{
Termokromik Pigment İçeren Kaplamalarda İşlem Sıcaklık Etkisi
}

\section{Temperature Effect in Thermochromic Pigment Containing Coatings}

\author{
Lale Civan $^{1}$ iD, Semra Kurama ${ }^{1}$ iD, Erhan Ayas 1 iD

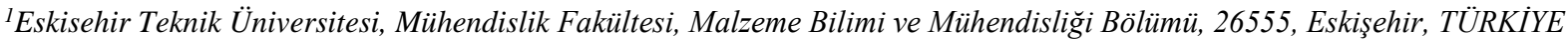

Başvuru/Received: 06/02/2021

Kabul / Accepted: 26/02/2021

Çevrimiçi Basım / Published Online: 23/05/2021

Son Versiyon/Final Version: 18/06/2021

\section{$\ddot{O} \mathbf{z}$}

Bu çalışmada, kaplama yapmak için ticari olarak temin edilebilen ve $33^{\circ} \mathrm{C}$ 'nin üzerinde yeşilden beyaza, $45^{\circ} \mathrm{C}$ 'nin üzerinde siyahtan beyaza ve $65^{\circ} \mathrm{C}$ 'nin üzerinde maviden beyaza renk değiştiren termokromik pigmentler kullanılmıştır. Farklı sıcaklıklarda isıl işlem süreci uygulanan kaplamalarda bağlayıcı olarak polivinilpirolidon kullanılmıştır. Hazırlanan kaplamaların renk, faz, mikroyapı analizleri yapılmış, renk değişim sıcaklıkları kızılötesi termometre ve kızılötesi termal kamera ile karakterize edilmiştir. Yapılan çalışmalar sonucunda, günlük hayatta yaşanılan olası sıcaklık değişimlerinin ve risklerin yaşam konforunu değiştirmeden bu yöntem ile tespit edilebileceği ortaya konulmuştur.

\section{Anahtar Kelimeler}

"Termokromik, Pigment, Kaplama, Renk değişimi, Sicaklık"

\begin{abstract}
In this study, commercially available thermochromic pigments that change color from green to white above $33^{\circ} \mathrm{C}$, black to white above $45^{\circ} \mathrm{C}$, and blue to white above $65^{\circ} \mathrm{C}$ were used to make coatings. Polyvinylpyrrolidone was used as a binder in coatings where heat treatment processes were applied at different temperatures. Color, phase, microstructure analyzes of the prepared coatings were done and the color change temperatures were characterized by an infrared thermometer and an infrared thermal camera. As a result of the performed studies, it has been revealed that possible temperature changes and risks experienced in daily life can be detected by this method without changing the comfort of life.
\end{abstract}

Key Words

"Thermochromic, Pigment, Coating, Color change, Temperature" 


\section{Giriş}

Akıllı malzemeler bir dış uyarana yanıt olarak fiziksel özelliklerini dinamik olarak değiştirebilir. Uyaran, uygulanan mekanik kuvvet, basınç, manyetik alan, elektrik alanı veya elektromanyetik radyasyon gibi fiziksel bir etkileşim şeklinde olabilir. Uyaran ayrıca, sıcaklık, pH veya kimyasal bileşim gibi malzemenin bulunduğu ortam koşullarında bir değişiklikten de oluşabilir (Rossi vd., 2021). Yapı malzemeleri, kentsel mekanın ısıl davranışında ve binanın enerji tüketiminde ve iç mekan çevre kalitesinde önemli bir rol oynar. Son zamanlarda, enerji kullanımını en aza indirgemek, iç ve dış mekan termal konforunu iyileştirmek ve kentsel aşırı ısınmayla mücadele etmek için etkili bir yöntem olarak optik yapı malzemelerine ve kaplamalara ilgi artmaktadır. Termokromik malzemeler gelişmiş optik malzemelerden biridir (Garshasbi \& Santamouris, 2019).

Termokromik malzemeler, sıcaklık değişiminin neden olduğu faz geçişi sonucu renk değiştirir ve sıcaklık değişimine yanıt olarak optik özellikleri tersine çevirebilir. Güneş enerjisini dinamik olarak yöneterek, yani sıcak mevsimlerde istenmeyen güneş 1sısı kazanımını sınırlandırarak ve soğuk mevsimlerde daha fazla güneş ısısı kazanımına izin vererek binanın güneş ısısı kazanımını düzenleyebilir (Cheng vd., 2018; Hu \& Yu, 2020). Termokromik malzemeler, hem endüstriyel makineler hem de mutfak aletlerinin yanı sira buzlu yol koşulları uyarıları için yol işaretlerinde de uygulama alanı bulabilir. Ayrıca, termokromik pigmentler binaların enerji verimliliğini artırmak için çatı kaplamalarında kullanılabilir veya artık şarj miktarını izlemek için pil test cihazlarına uygulanabilir (Ferrara \& Bengisu, 2014). Günümüzde farklı araştırma alanlarında, dış uyaranlar tarafından kontrol edilen özelliklere sahip akıllı malzemelerin geliştirilmesi için önemli çabalar sarf edilmektedir. Diş parametrelerin değişmesiyle tersine değişen optik özelliklere sahip kromojenik malzemeler de akıllı yapı malzemeleri olarak ilgi çekicidir (Pérez vd., 2018). Kromojenik malzemeler, akıllı malzemelerin bir alt sınıfını oluşturur ve rengi tersine dönüştürebilir özelliğe sahiptir (Ferrara \& Bengisu, 2014). Rengi tersine çevirebilen kromojenik malzemeler, çevre ile etkileşime giren kaplamaların oluşturulmasında kullanılabilir ve kullanıcıya önemli bilgiler sağlar (Calovi vd., 2021). Renk değişiklikleri, malzemeler isıtıldı̆̆ında veya soğutulduğunda moleküllerin yapi içerisinde geçişine veya dönüşümüne bağlı bir süreçtir (Rajadurai vd., 2020).

Termokromik kaplamalar, çarpıcı estetik özelliklerinin yanı sıra, enerji tasarrufundaki yeniliklere kapı açar (Aklujkar \& Kandasubramanian, 2020). Termokromik kaplamalar, güneş ışınımı emilimlerini sıcaklıklarına göre dinamik olarak değiştirebilirler. Renk geçiş sıcaklığından daha yüksek olduğunda, açık tonlarda görünebilir ve daha fazla güneş radyasyonu yansıtabilirler, renk geçiş sıcaklığından daha düşükken, koyu tonlarda görünürler ve daha fazla güneş radyasyonu emerler. Bu nedenle binaların hem soğutma hem de 1sıtma yüklerinin azaltılmasına katkıda bulunurlar (Santamouris vd., 2011). Termokromik kaplamalar, binanın isitma ve soğutma yükünü azaltmada ve kentsel termal ortamı iyileştirmede büyük uygulama potansiyeline sahiptir (Zhang \& Zhai, 2019). Binaların ısıtma ve soğutma yükleri, güneş ışınımının soğurulması ve yansıması ile yakından ilişkilidir. Bu nedenle bina kaplama malzemeleri, bina enerji tüketimini büyük ölçüde etkileyebilir. Güneş radyasyonunun bina soğurmasını düzenlemek için yeni tür malzemeler kullanarak bina iklimlendirme enerji tüketimini azaltmak için birçok araştırma yapılmıştır (Yuxuan vd., 2020). Termokromik kaplamalar hali hazırda ambalajlamadan giysiye ve tıbbi ürünlere kadar çeşitli alanlarda da kullanılmaktadır (Berardi vd., 2020). Bu kaplamalarda sıcaklık belirli bir değerden yüksek olduğunda kaplamanın rengi değişir. Sicaklık bu değerden düşük olduğunda, orijinal renk eski haline döner (Yan vd., 2020). Sicaklık geçiş sıcaklığından daha düşük olduğunda, termokromik malzemeler koyu renkler sergiler ve güçlü güneş enerjisi emilimi gösterir. Geçiş sıcaklığının üzerinde ise açık renkler sunarlar ve yüksek güneş yansıtma özelliğine sahiptirler (Hu \& Yu, 2019). Doğası gereği tersine çevrilebilir organik termokromik sistemlerde, belirli bir sıcaklığın üzerinde 1sıtma, renkte daha koyu tonlardan daha açık tonlara bir değişikliğe neden olur. Bu geçiş, pigmentlerin moleküler yapısının, görünür renkte spektral bir değişim üreten termal olarak tersine çevrilebilir bir dönüşümü ile elde edilir. Sıcaklık, renk değiştirme noktasının altına düştüğünde, sistem termal olarak kararlı durumuna geri döner (Karlessi \& Santamouris, 2015). Bu süreçte kaplamalarda kullanılan termokromik pigmentler mikrokapsüllenmiş termokromik tozlardır.

Termokromik mikrokapsüllerin kompozisyonlara ilavesi kaplamaya sıcaklık değişimi ile tetiklenebilen renk değiştirme fonksiyonu kazandırır (Pedaballi vd., 2019). Sıcaklıkla tersine değişen optik özelliklere sahip kapsüllenmiş tersinir termokromik pigmentler, enerji verimliliğini artırmak ve binaların çevresel etkisini azaltmak için bina kaplamalarında kullanılmıştır (Pérez vd., 2020). Termokromik mikrokapsüllerin sıcaklığa duyarlı tersinir sistemleri organik tersinir, inorganik tersinir ve sıvı kristal tersinir kategorilerine ayrılabilir. Termokromik bir sistemdeki çözücüler, sıcaklığa duyarlı malzemelerin termokromik sıcaklığını belirler. Isıya duyarlı renk değiştirme sıcaklığı genellikle kullanılan çözücünün değiştirilmesi ile değiştirilir (Yan vd., 2019). Piyasada bulunan kapsüllenmiş tersinir termokromik pigmentler renk oluşturucu, renk geliştirici ve çözücü olmak üzere üç bileşenden oluşur. Düşük sıcaklık için, çözücü katı fazdadır ve renkli durum, renk oluşturucu ile geliştirici arasındaki reaksiyondan kaynaklanır. Sıcaklık yükseldikçe, çözücü erir ve çözücü-geliştirici reaksiyonu baskın hale gelir ve renksiz duruma yol açar. Pigment bileşenleri, zararlı ortamlardan koruma olarak organik mikrokapsüller içine alınır (Pérez vd., 2020).

Termokromik malzemelerin bina kaplamalarında uygulanabilmesi için dönüşüm sıcaklığının, uygulandığı ortamın sıcaklığına uygun olması gerekir. Bu nedenle sistem için malzemelerin, geçiş sıcaklıkları çevre ile uyumlu olacak şekilde seçilir. Boyanın mikrokapsülleme adımı tamamlandıktan sonra, sonraki adım termokromik kaplamalar oluşturmak için bunları kaplama sistemlerine eklemektir. Kaplamanın film oluşturucu öğesi olan bağlayıcı, kürlendikten sonra alt tabaka üzerinde kalan kaplamanın polimer desteğidir. Kaplamanın viskozitesini kontrol etmek için kullanılan çözücü uçucudur ve yüzey üzerindeki uygulamada buharlaşır. Kaplamalarda pigmentler ve boyalar, rengi indüklemek için boya sistemine dahil edilir (Aklujkar \& Kandasubramanian, 2020). Polivinilpirolidon (PVP), hazırlanan kompozisyonlarda bağlayıcı olarak kullanılan kimyasal kararlılı̆̆ı ve çözünürlüğü yüksek bir 
polimerdir (Kuźmińska vd., 2020). Son yıllarda, termokromik malzemeler ve bunların polimerlere dahil edilmesi sık sık incelenmiştir. Bu malzemeler muazzam bir ilerleme kaydetmiş ve gelişmiş teknolojide giderek daha önemli hale gelmiştir (Štaffová vd., 2021). Akıllı davranışa sahip termokromik kaplamaları, uygun bağlayıcılara eklenen mikrokapsüllenmiş organik pigmentlere dayalı olarak literatürde sunulmuştur (Karlessi vd., 2009). Literatürde Rossi vd. hazırladığı kompozisyonda ise pigmentin dağılmasını ve altlığa yapışmasını sağlamak amacıyla epoksi tipi bağlayıcı kullanılmıştır (Rossi vd., 2021). Hazırlanan kaplama çözeltileri uygulama yüzeyinde sabitlenebilmek için ısıl işlemler uygulanmaktadır. Isıl işlem kaplamaların yapısal olarak iyileştirilmesini ve stresin giderilmesini sağlar (Chen \& Wei, 2001).

$\mathrm{Bu}$ çalışmada üç farklı renk pigment ile bağlayıcı kullanılarak oluşturulan termokromik kaplamaların sıcaklık değişimine bağlı olarak davranışları incelenmiştir. Hazırlanan kaplamaların kullanım ömrünü belirlemek amacıyla 30 ay sonra kaplamaların termokromik performansı tekrar değerlendirilmiştir. Numunelerin ilk yapılışından 30 ay geçmesine rağmen termokromik performansında bir azalma gözlenmemiş̧tir. Uzun süre 1sıtma ve soğutma çevirimine tabi tutulan numuneler sürekli renk değiştirmeye devam etmiştir.

\section{Materyal ve Metot}

Çalışmada kullanılan polivinilpirolidon (PVP, K 90, ortalama moleküler ağırlık: 360,000, Tokyo Chemical Ind. Co., Ltd.), 2-propanol (Merck, ABD) ve kuvars lameller (Bilim-Med Ltd.) firmalarından temin edilmiştir. Hali Chemical Co., Ltd. firmasının spesifikasyonuna göre üretilen, $33,45 \mathrm{ve} 65^{\circ} \mathrm{C}$ aktivasyon sıcaklığına sahip yeşil, siyah ve mavi renkli tersinir termokromik pigmentler toz formundadır. Homojen viskozite, sıcaklık kararlılı̆̆ı, iyi uyumluluk ve çapraz bağlama özellikleri nedeniyle polimer olarak polivinilpirolidon seçilmiştir. Yüzey temizleme işlemleri için kuvars lameller $(25 \mathrm{~mm}$ x $25 \mathrm{~mm})$ sırasıyla aseton, etanol ve saf suda 10 'ar dk.' llk süre ile ultrasonik banyoda temizlenmiştir. Yüzeyleri temizlenen lameller $10 \mathrm{dk}$. süre ile etüvde kurutulmuştur. Termokromik pigmentlerin polivinilpirolidon içinde daha iyi dispersiyonu için 2-propanol kullanılmıştır. 4 g polivinilpirolidon (bağlayıcı) ve $40 \mathrm{ml}$ 2-propanol (çözücü) ilave edilerek hazırlanan karışım 2 gün bekletilerek kimyasalların birbiri içinde çözünmesi gerçekleştirilmiştir. $\mathrm{Bu}$ işlemden sonra $2 \mathrm{~g}$ termokromik pigment ilave edilmiş karışımlar 1 gün daha bekletilerek karışımların yaşlanması sağlanmıştır. Karışım hazırlama prosesi Şekil 1'de verilmektedir. Hazırlanan kaplama karışımları kuvars lameller üzerine rakle ile uygulanmıştır. Kaplamalar tamamen yayıldıktan sonra oda sıcaklığında kurutulmuştur (Şekil 2). Kaplama yüzeylerinin homojenleştirilmesi, stres giderilmesi ve kaplamanın altlığa tutunmasını sağlamak için farklı sıcaklıklarda 1sıl işlemler yapılmıştır (Şekil 3-4). Kaplamaların 1sıl işlemi polivinilpirolidon polimerini çapraz bağlamıştır.

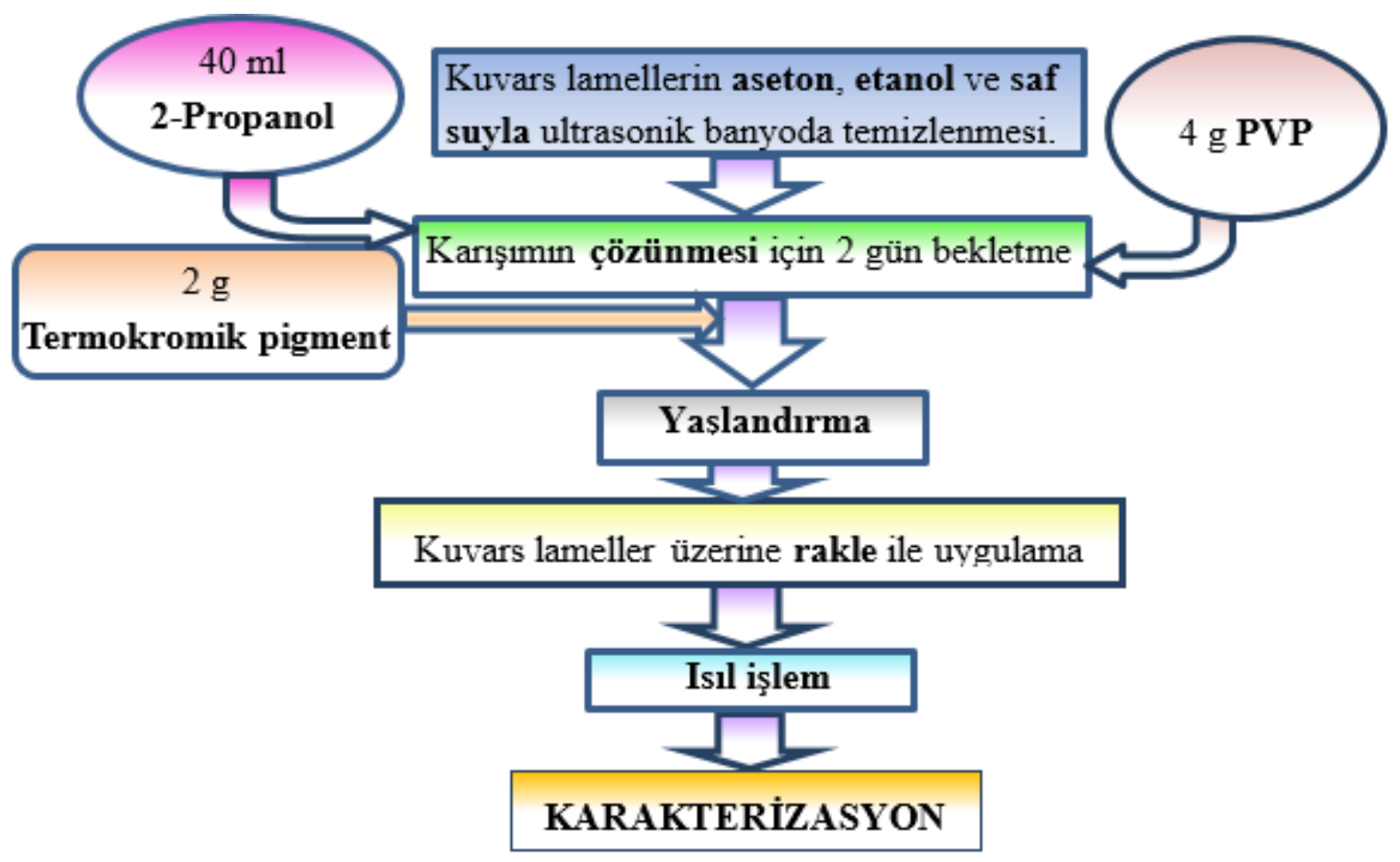

Şekil 1. Kaplama karışımı hazırlama akım şeması 

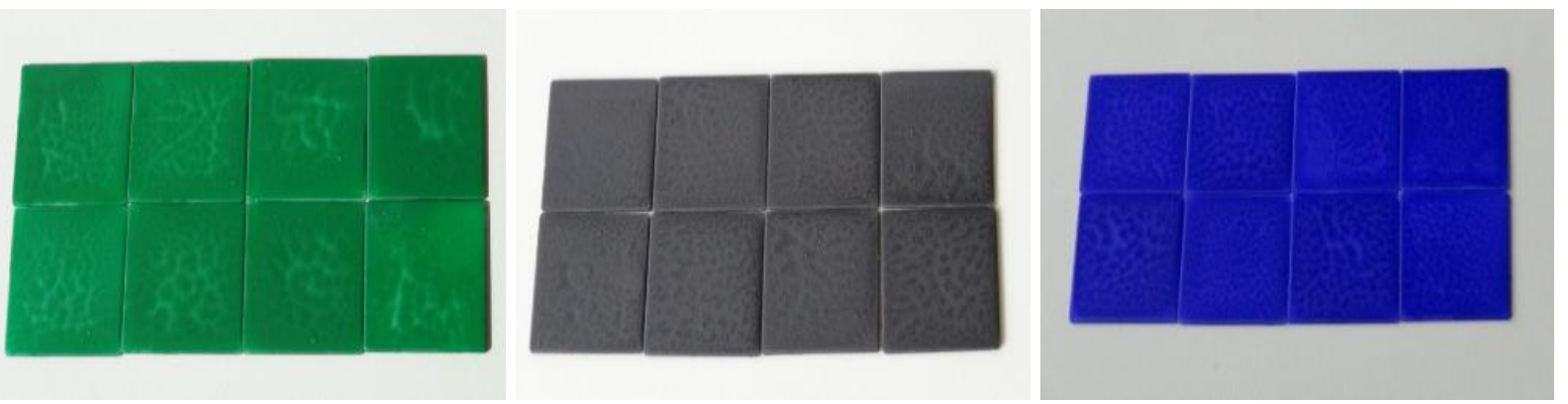

Şekil 2. Yeşil, siyah, mavi pigment ile 1 gün bekletilen $1 s ı$ işleme tabi tutulmamış numunelerin yüzeyi
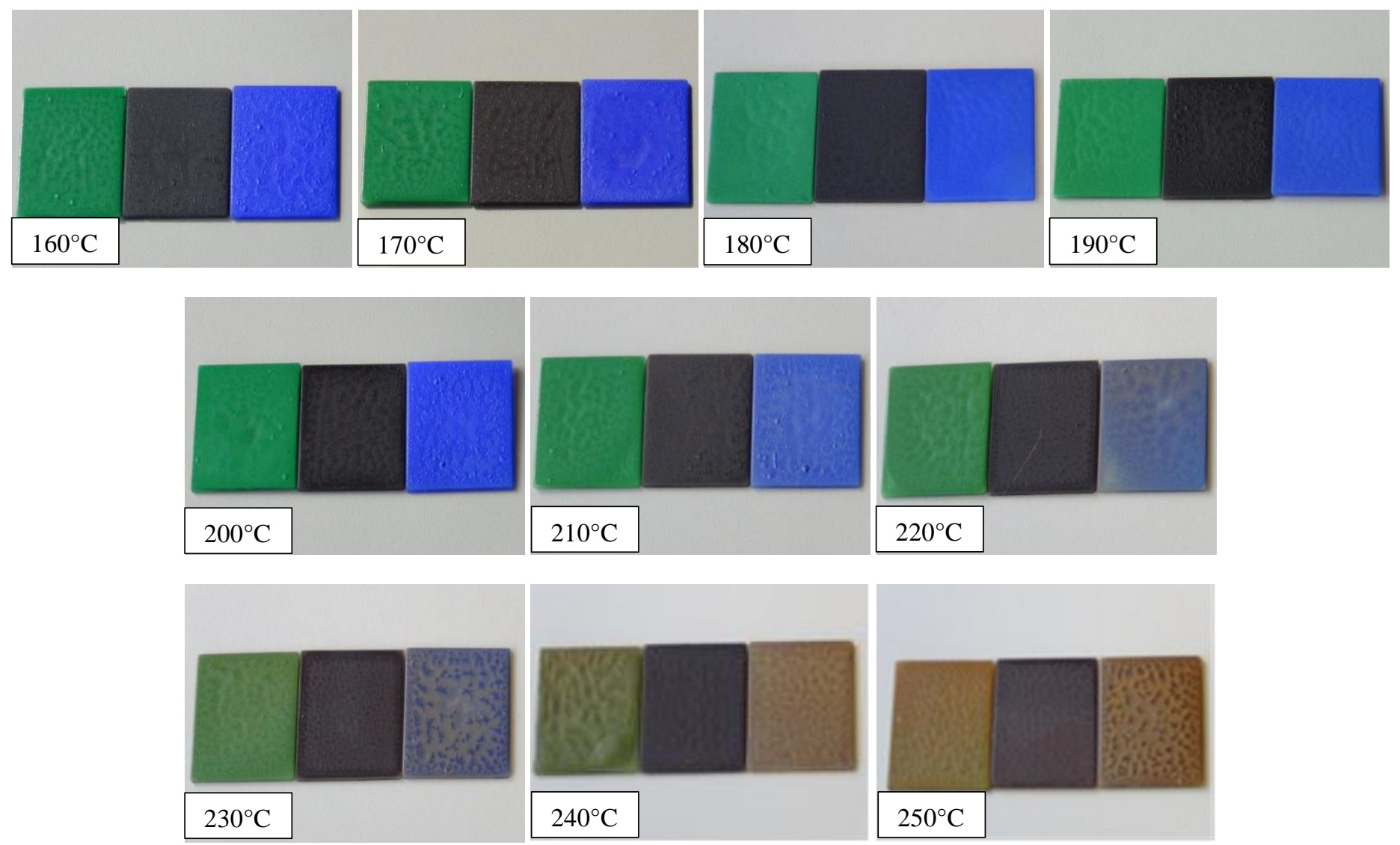

Şekil 3. Farklı 1 sıl işlem sıcaklıklarına $\left(160-250^{\circ} \mathrm{C}\right)$ tabi tutulmuş kaplamalar $\left(25^{\circ} \mathrm{C} / \mathrm{dk}\right.$. 1sıtma hızında $30 \mathrm{dk}$. bekleme süresinde $)$
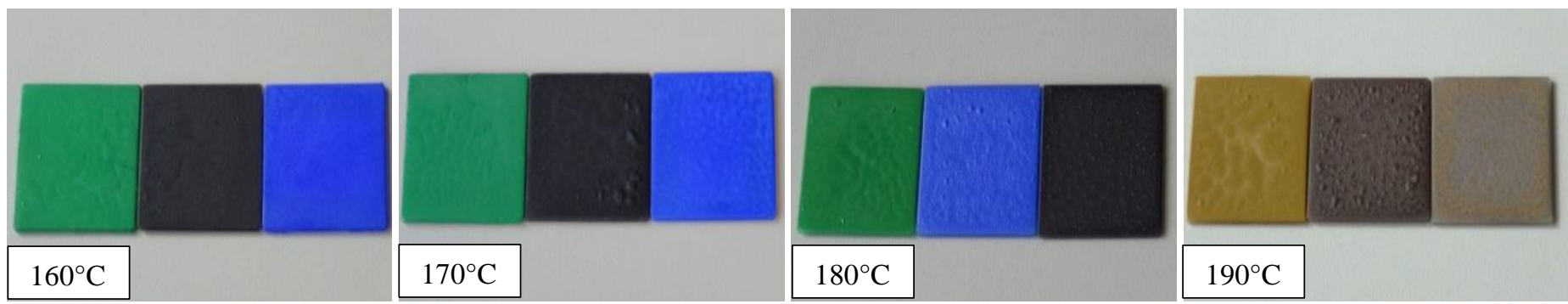

Şekil 4. Farklı vakumlu etüvlerde farklı 1sıl işlem sıcaklıklarına $\left(160-180^{\circ} \mathrm{C}\right)$ tabi tutulmuş kaplamalar $(10 \mathrm{dk}$. bekleme süresinde, 800 mbar vakum altında) ve $190^{\circ} \mathrm{C}$ 'de 3,5 saat bekleme süresinde $600 \mathrm{mmHg}$ vakum altında 


\section{Bulgular}

\subsection{X-Işınları Analizi}

Termokromik pigmentlerin fazlarının analizi Rigaku MiniFlex 600 marka X-1şınları kırınım cihazı (XRD) ile, Cu tüpüne $40 \mathrm{kV}$ gerilim ve $15 \mathrm{~mA}$ akım uygulanarak elde edilen $\mathrm{CuK} \alpha$ ş̧ınımı kullanılarak gerçekleştirilmiştir. Tüm ölçümler 10 ve 70 dereceler arasında $1 \%$ dk. çekim ve $0,02^{\circ}$ tarama hızıyla gerçekleştirilmiştir. Kaplanan kuvars lameller metal numune tutuculara sabitlenerek ve incelenen numune ile numune tutucusu aynı düzleme getirilerek analiz işlemi gerçekleştirilmiştir. $160^{\circ} \mathrm{C}^{\prime} \mathrm{de}$ ssıl işlem görmüş yeşil, siyah ve mavi termokromik kaplamaların XRD deseni Şekil 5'te verilmiştir. Oluşan fazlar yeşil kaplama için bakır klorür etilendiamin ve metil stearat'tir. Ayrıca yeşil termokromik pigmente yapılan X-ışını difraksiyonu sonuçları da bakır klorür etilendiamin ve metil stearat fazının varlığını doğrulamaktadır. Yapılan bu analizde yeşil renk termokromik pigmentin içeriğinde bakırın bulunduğu tespit edilmiştir. Metil stearat bileşiği sıklıkla, üç bileşenli termokromik pigmentlerde geçiş sıcaklığını tanımlayan çözücü olarak kullanılır (Zhang vd., 2017). Pigment bileşiminin \%50'den fazlasını temsil eder. Bu karakteristik piklerin görünümü, metil stearatın, X-1şını kırınım deseninin ölçümü sırasında katı fazda olduğu anlamına gelir. Bu, ölçümlerin, pigment geçiş sıcaklığından daha düşük bir ortam sıcaklığında gerçekleştirilmesi gerçeğiyle tutarlıdır (Pérez vd., 2020). Siyah kaplama için setil alkol, mavi kaplama için setil alkol ve 4-hidroksi-N, $\mathrm{N}$-dimetil- tryptamine fazları tespit edilmiştir.

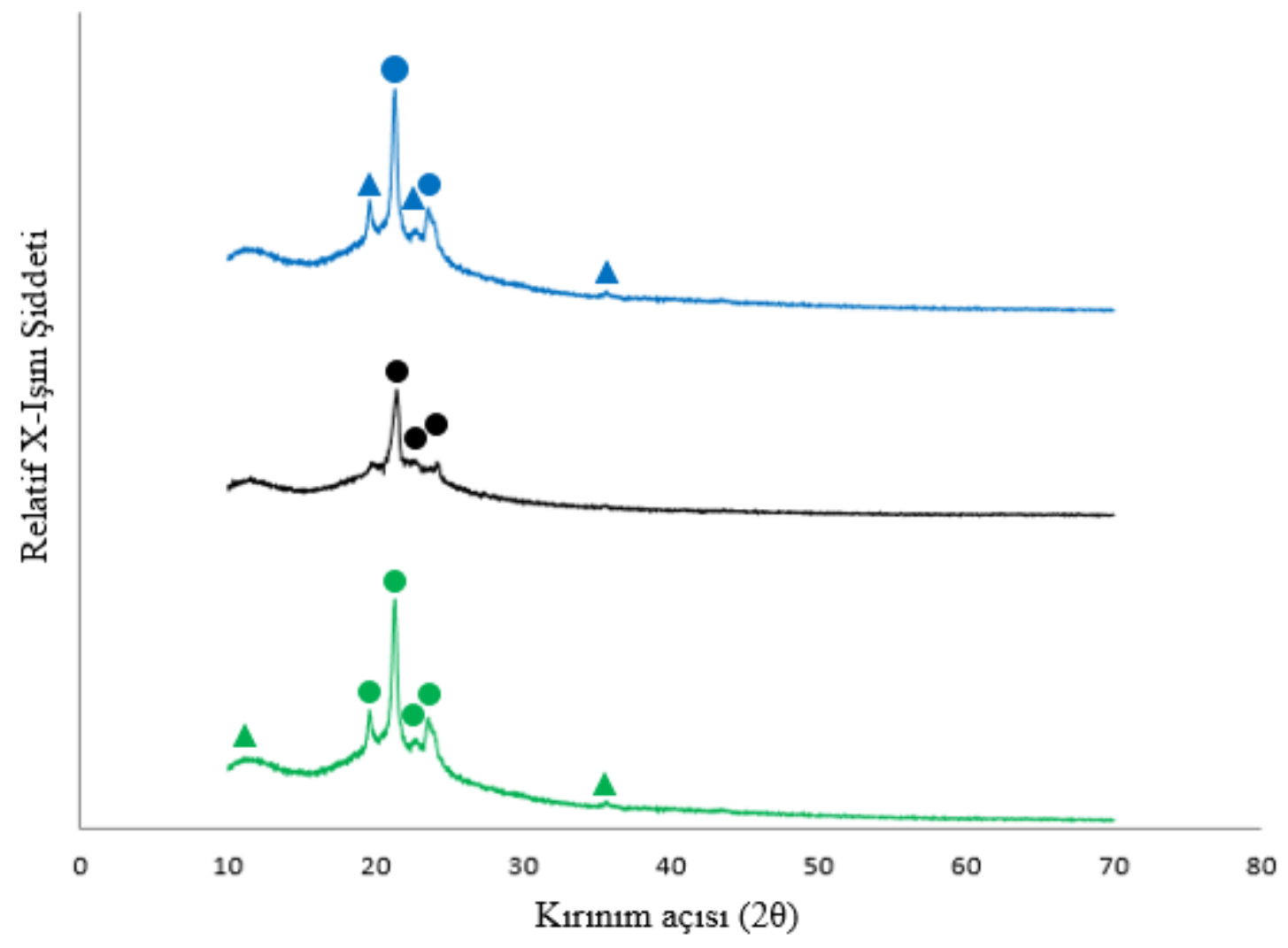

Şekil 5. $160^{\circ} \mathrm{C}^{\prime}$ de 1 ssıl işlem görmüş yeşil, siyah ve mavi termokromik kaplamanın XRD analizi [ $\bigcirc$ : Metil stearat, $\Delta$ : Bakır klorür etilendiamin, : Setil alkol, $\bigcirc:$ Setil alkol, $\mathbf{\Delta}:$ 4-hidroksi-N, N-dimetil- tryptamine]

\subsection{Renk Analizleri}

Termokromik kaplamaların renk analizleri Konica Minolta CM 2300D marka spektrofotometre cihazıyla yapılmışıtır. Kaplamaların CIE L*a*b* değerleri, kolorimetrik özellikleri karakterize etmek için ölçülmüştür. Bu renk ölçüm sisteminde $\mathrm{L}^{*}$ parametresi, siyah için $L^{*}=0$, beyaz için $L^{*}=100$ 'dür ve rengin açık veya koyuluğunu ifade eder. a * yeşil(-)/kırmızı(+) eksen iken $b * \operatorname{mavi}(-) / \operatorname{sar}(+)$ eksendir. $\mathrm{L} * \mathrm{a} * \mathrm{~b} *$ değerleri elde edildikten sonra, toplam renk farkı $\Delta \mathrm{E} *$ aşağıdaki formüle göre hesaplanabilir:

$$
\Delta \mathrm{E}^{*}=\sqrt{\left(\Delta \mathrm{L}^{*}\right)^{2}+\left(\Delta \mathrm{a}^{*}\right)^{2}+\left(\Delta \mathrm{b}^{*}\right)^{2}}
$$

Tablo 1'de spektrofotometre cihazından elde edilen sonuçlar, Şekil 6' da ise kaplamaların reflektans spektrumu gösterilmektedir. İnsan gözü $380 \mathrm{~nm}$ ile $780 \mathrm{~nm}$ arasındaki dalga boylarını algılayabilir, bu nedenle elektromanyetik spektrumun bu bölümüne görünür ışı $\mathrm{k}$ denir. Yeşil ışık, elektromanyetik spektrumun yaklaşık $510 \mathrm{~nm}$ 'lik dalga boyuna sahip aralığına denk gelen kısmıdır. Tüm dalga boyları 
birden aynı anda gözümüze ulaşırsa bunu beyaz, hiç ışık ulaşmazsa siyah olarak algılarız. Mavi ışığın dalga boyu ise 380-500 nm arasındadır.

Tablo $1.33^{\circ} \mathrm{C}$ yeşil, $45^{\circ} \mathrm{C}$ siyah ve $65^{\circ} \mathrm{C}$ mavi renk kaplamaların renk değerleri

\begin{tabular}{ccccc}
\hline Numune Adı & $\mathbf{L}^{*}$ & $\mathbf{a}^{*}$ & $\mathbf{b}^{*}$ & $\Delta \mathbf{E}^{*} \mathbf{a b}$ \\
\hline $33^{\circ} \mathrm{C}$ yeşil renk kaplama & 43,80 & $-27,69$ & 11,47 & 23,59 \\
$45^{\circ} \mathrm{C}$ siyah renk kaplama & 28,71 & $-1,17$ & $-0,51$ & 14,95 \\
$65^{\circ} \mathrm{C}$ mavi renk kaplama & 42,04 & 18,05 & $-56,53$ & 11,41 \\
\hline
\end{tabular}

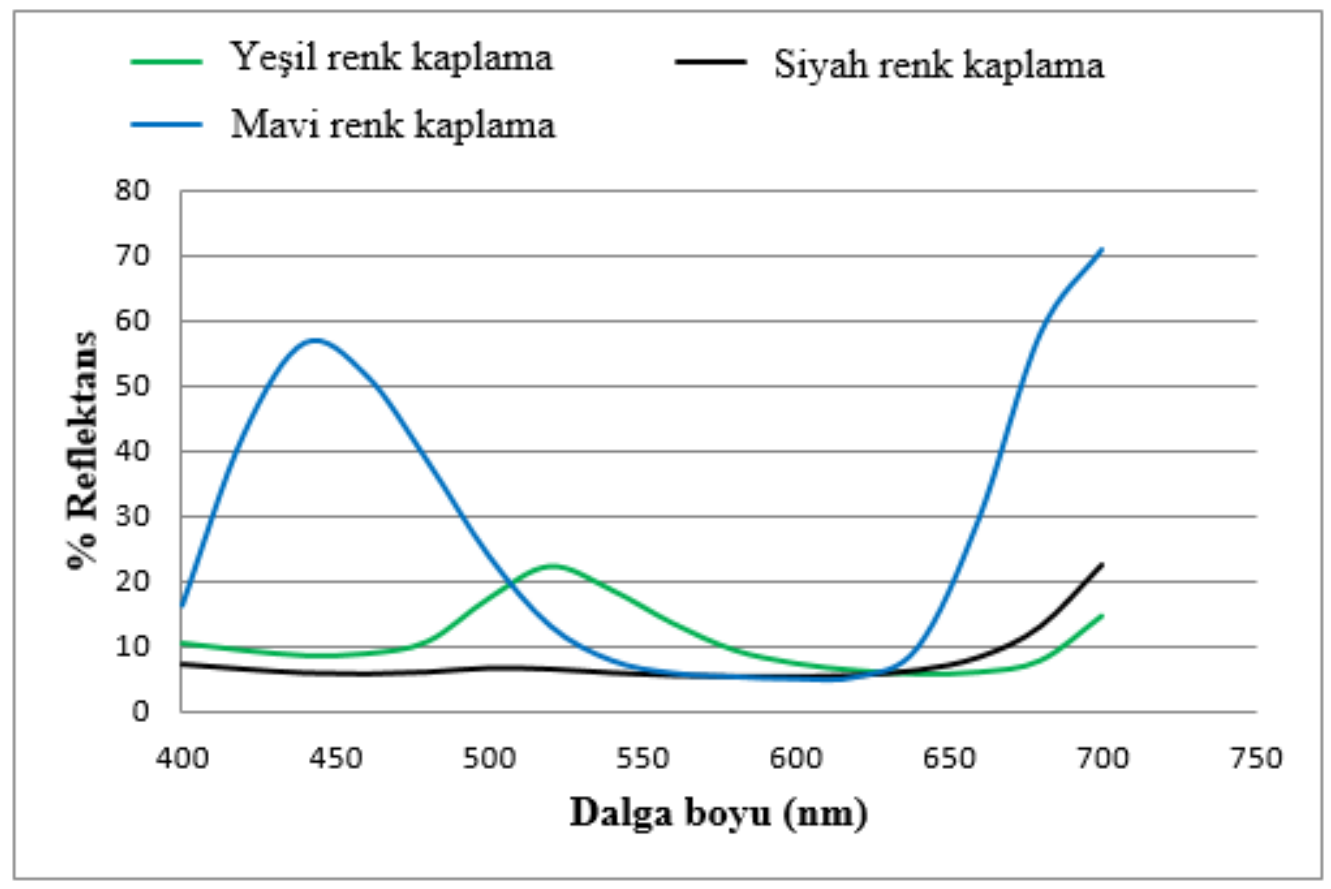

Şekil 6. Kaplamaların reflektans spektrumu

\subsection{Renk Değişiminin Sıcaklığa Bağlı Analizi}

Oluşturulan kaplamaların renk değişim sıcaklığı kızılötesi termometre (GM320) ile tespit edilmiştir. Renk değiştirme sıcaklıkları gözle renk değişimi gözlemlenerek belirlenmiştir. Numune bir taraftan hot plate'ten ısı alırken diğer taraftan yüzeyden ısı kaybeder. Kızılötesi termometre lazerle noktasal ölçüm yapmaktadır. Bu yüzden numunenin orta kısmında sıcaklıklar yüksek çıkarken numunenin kenarındaki sıcaklılar düşük çıkmıştır. Oluşturulan kaplamaların + ve - standart sapması verilen değerler arasındadır. Yüzey sıcaklığı $33^{\circ} \mathrm{C}$ 'nin üzerine çıktığında, termokromik kaplama sıcaklığının artması nedeniyle rengi yeşilden beyaza değiştirmeye başlamıştır. Şekil 7.'de gösterildiği üzere yüzey sıcaklığ $140^{\circ} \mathrm{C}$ olduğunda ise kaplama rengi beyaza dönmüştür. Yeşil termokromik kaplama soğuturken $33^{\circ} \mathrm{C}^{\prime}$ de tekrar yeşil renge dönmeye başlamıştır (Şekil 8). Siyah termokromik kaplama isitırken ve soğuturken $40^{\circ} \mathrm{C}$ 'de renk değiştirmeye başlamıştır (Şekil 9-10). Mavi termokromik kaplama 1 sııtırken $55^{\circ} \mathrm{C}$ 'de renk değiştirmeye başlayıp, yüzey sıcaklığı $60^{\circ} \mathrm{C}$ 'ye ulaştığında tamamen beyaz renge dönmüştür (Şekil 11). Soğuturken mavi termokromik kaplama $55^{\circ} \mathrm{C}^{\prime}$ de renk değiştirmeye başlamıştır (Şekil 12). Isı ile renk geçişi işlemiyle tüm numunelerde renk değişimi belirgindir. Termokromik pigment kullanılarak oluşturulan kaplamalar, termokromik özellik göstererek sıcaklıkla birlikte renk değiştirme özelliğine sahiptir. Geçiş sıcaklıklarından yüksek sıcaklıklar için, malzeme yüksek yansıtma ile ilişkili açık renk gösterirken, daha düşük sıcaklıklar için düşük yansıma ile ilişkili koyu renk gösterir. Aktivasyon sıcaklığı 33,45 ve $65^{\circ} \mathrm{C}^{\prime}$ de olan üç ticari tersinir termokromik pigmentle yapılan kaplamaların sıcaklığın fonksiyonu olarak renk değişimi değerlendirilmiştir. Oluşturulan kaplamalar, dikkate değer geri dönüşümlü termokromik renk değişimi sergilemiştir. 

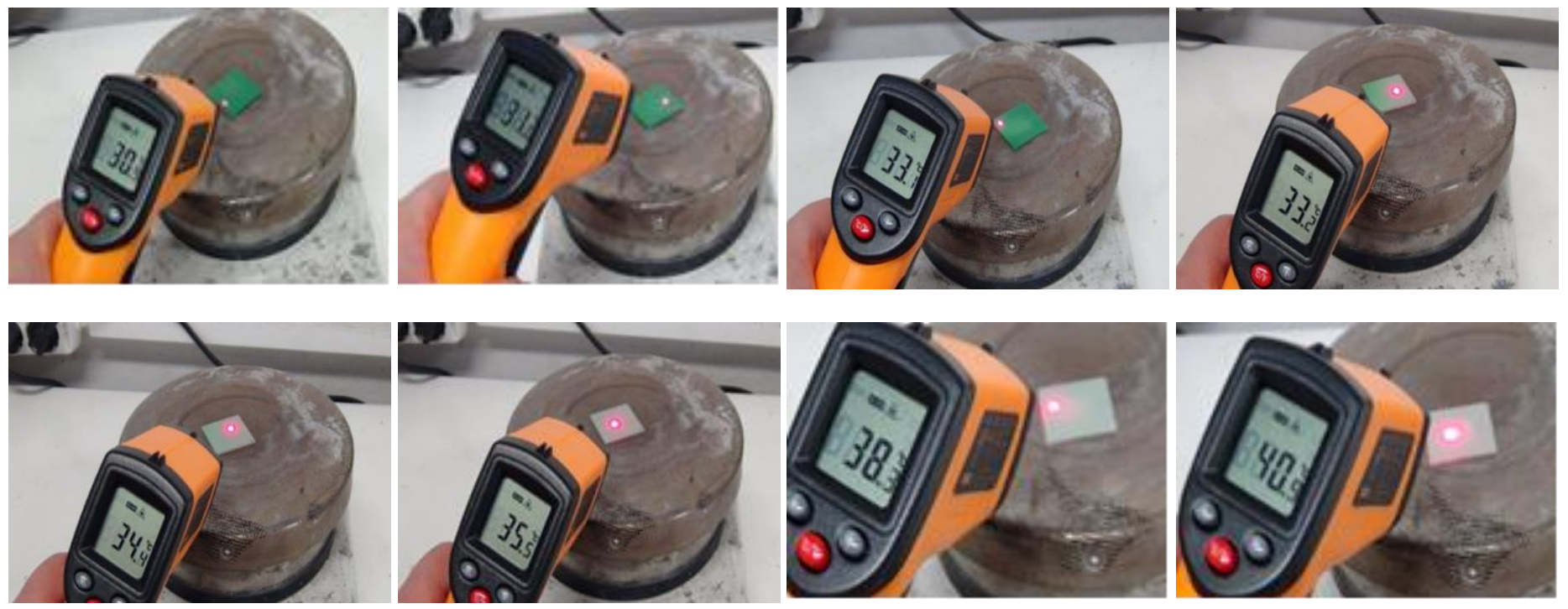

Şekil 7. Yeşil renk termokromik kaplamanın artan sıcaklıkla renk değişimi
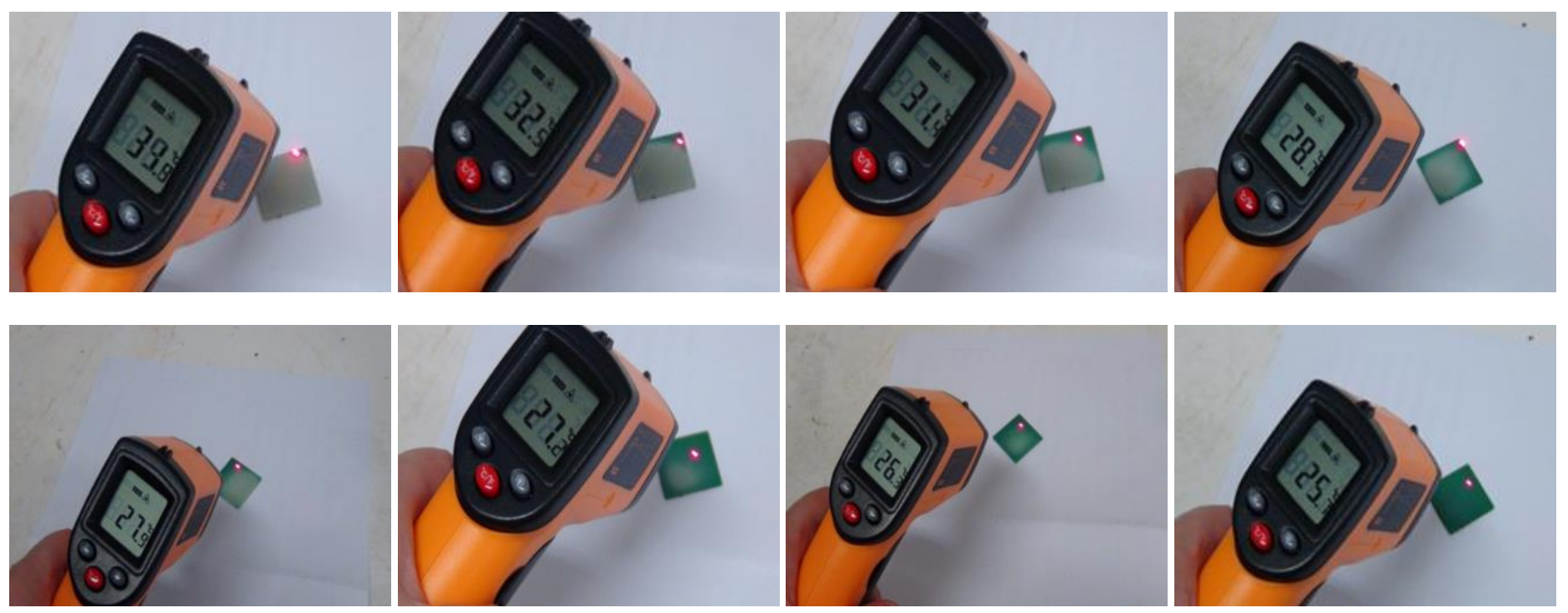

Şekil 8. Yeşil renk termokromik kaplamanın azalan sıcaklıkla renk değişimi
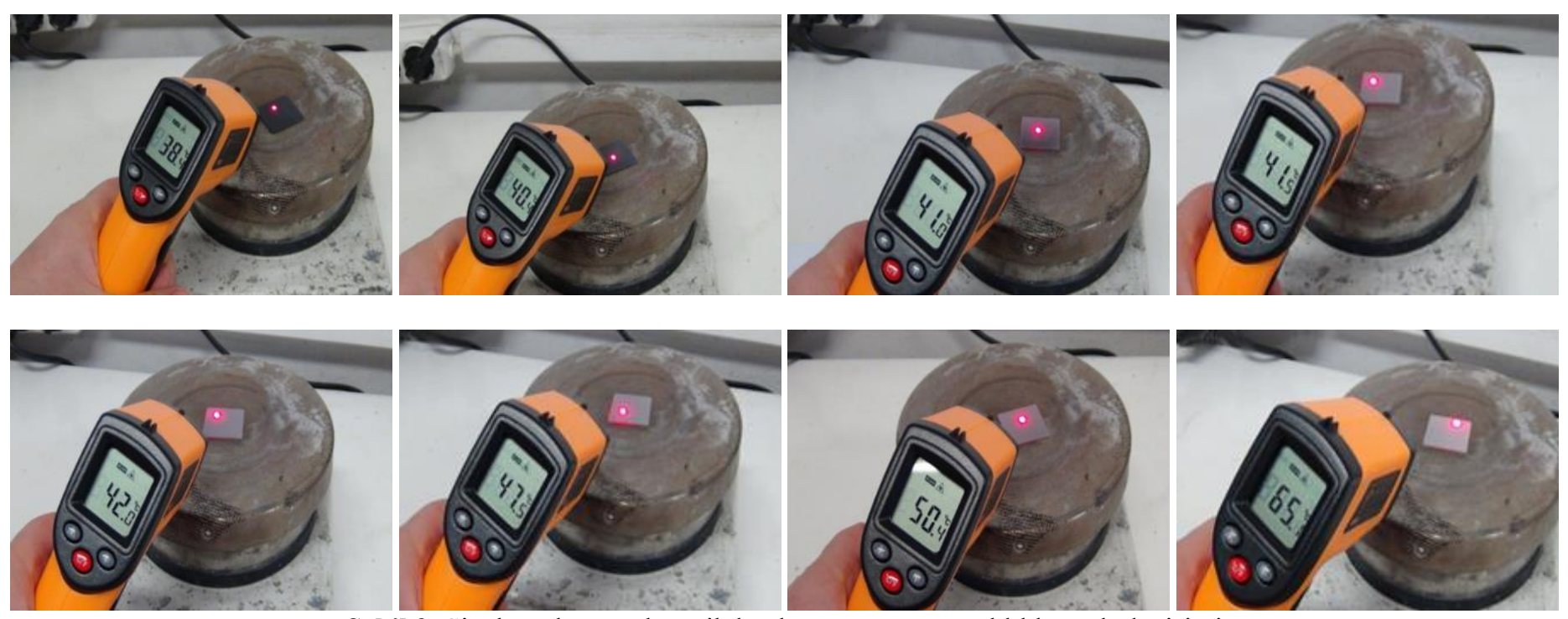

Şekil 9. Siyah renk termokromik kaplamanın artan sıcaklıkla renk değişimi 

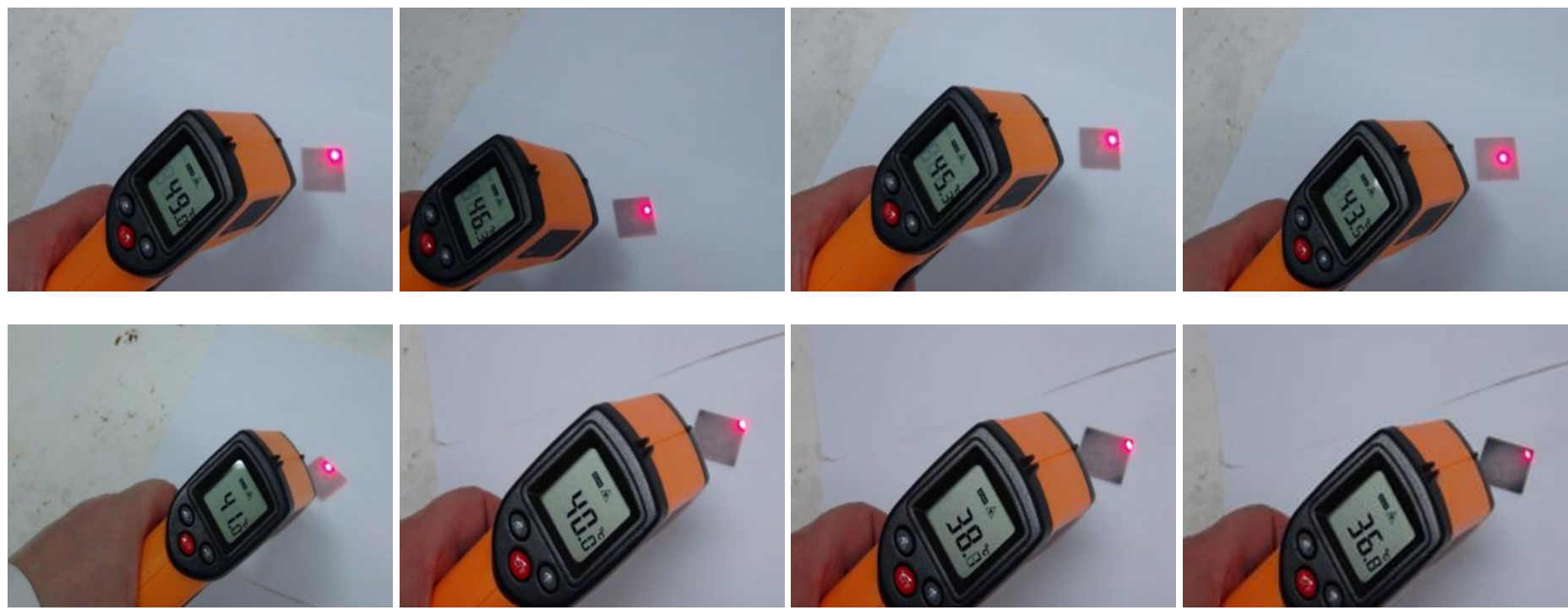

Şekil 10. Siyah renk termokromik kaplamanın azalan sıcaklıkla renk değişimi
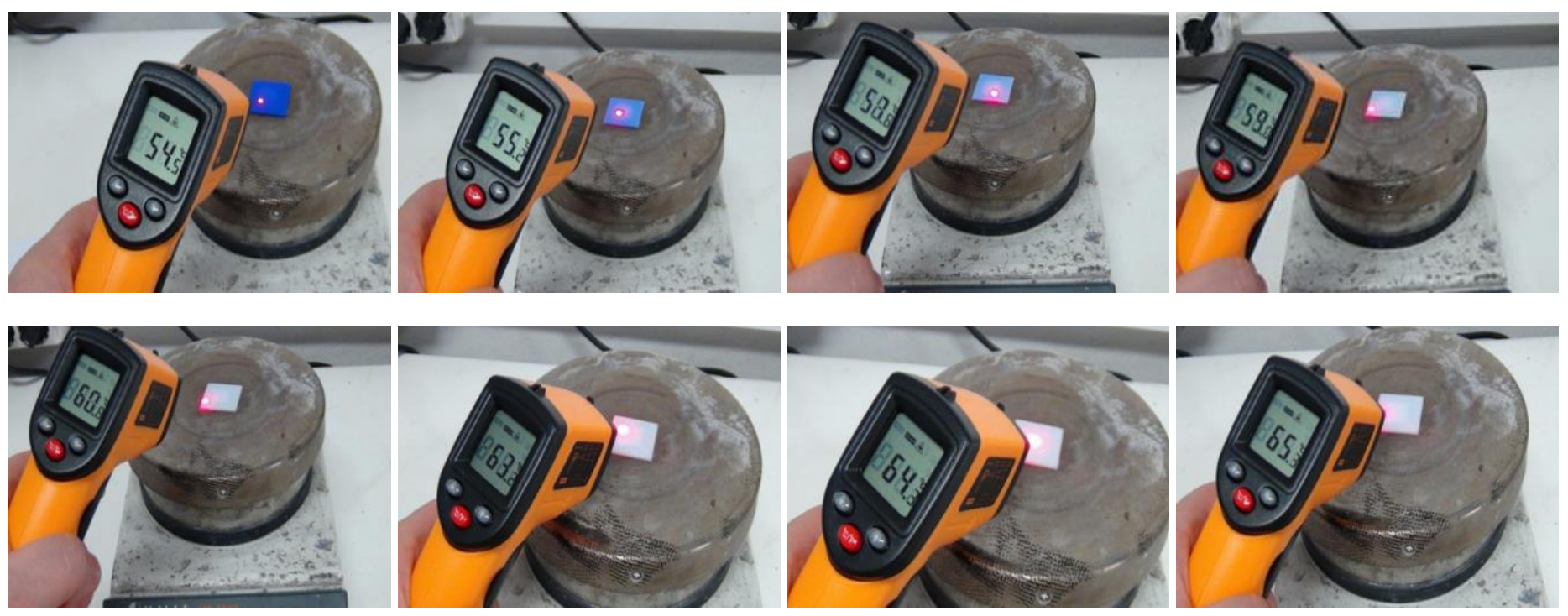

Şekil 11. Mavi renk termokromik kaplamanın artan sıcaklıkla renk değişimi
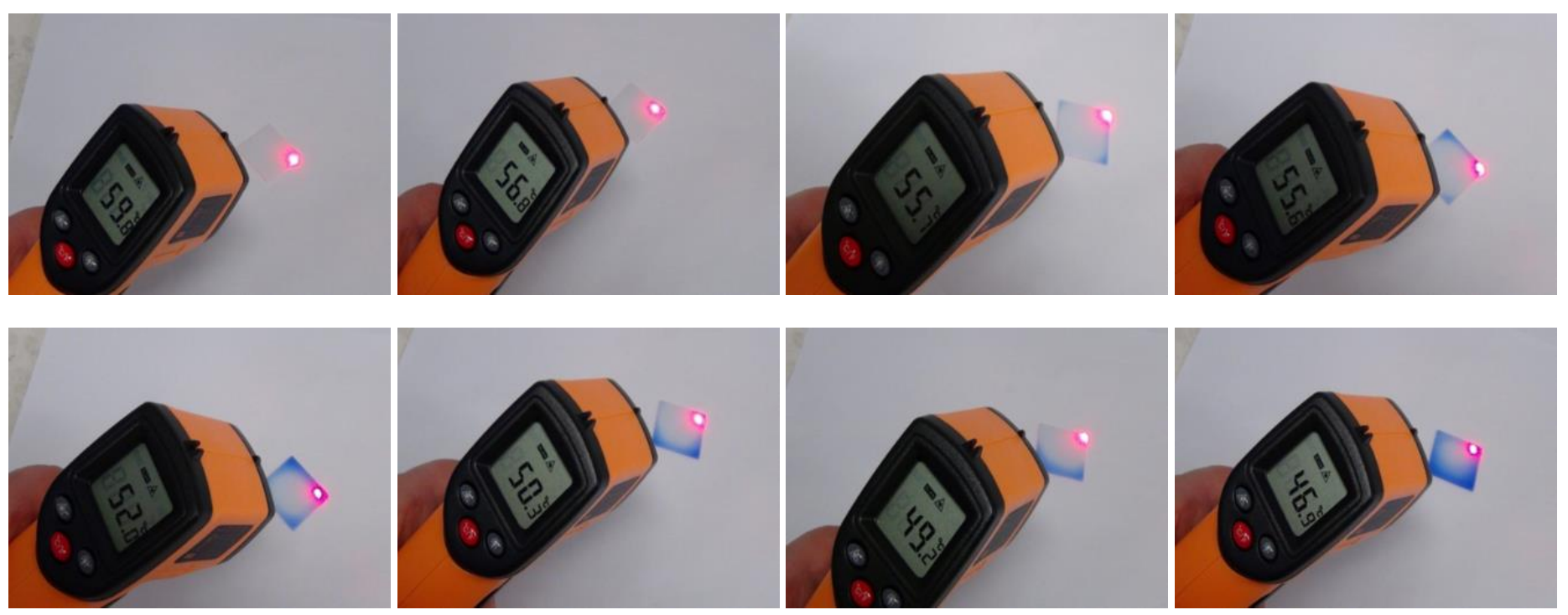

Şekil 12. Mavi renk termokromik kaplamanın azalan sıcaklıkla renk değişim 


\subsection{Ay Sonra Kaplamaların Termokromik Performansının Değerlendirilmesi}

Farklı 1sıl işlem sıcaklıklarına tabi tutulmuş tüm kaplamalar yapılışından 30 ay sonra tekrar incelendiğinde renklerinin oluşturulduğu şekilde bozulmadan durduğu görülmüştür. Şekil 13 'te yapılışından 30 ay geçen $160^{\circ} \mathrm{C}$ 'de 1 sil işlem sıcaklığına tabi tutulmuş kaplamalar gösterilmektedir. Bu kaplamaların 1sıl özellikleri tekrar incelendiğinde uzun süre ssıtılıp soğutulan numunelerin geri dönüşümlü termokromik performansa sahip olduğu belirlenmiştir. Şekil 14-16, 30 ay sonra 1sıtırken numunelerin renk değişimini göstermektedir. T-02D marka kızılötesi termal kamera ile de kaplamaların isıl özellikleri incelenmiştir (Şekil 17). Kızılötesi termal kamera görüntülerinden yeşil numunenin ssitırken $40,2^{\circ} \mathrm{C}$ 'de, mavi numunenin ise ssıtırken $60^{\circ} \mathrm{C}$ 'de beyaz renkte olduğu görülmüştür. Ayrıca kızılötesi termal kamera ile yapılan incelemede isıtırken siyah termokromik kaplamanın $40,5^{\circ} \mathrm{C}$ 'te renk değiştirmeye başladığ gözlemlenmiştir. Bu sonuçlar önceden yapılan kızılötesi termometre ssıl incelemeleriyle de uyumludur. Geçen bu uzun süre sonucunda numunelerin termokromik performansında bir değişme görülmemiştir. Numuneler uzun süre 1sıtma ve soğutma çevirimine tabi tutulduğunda bile 1sıtıldığında beyaz renge soğutulduğunda ise kendi rengine geri dönmüştür.

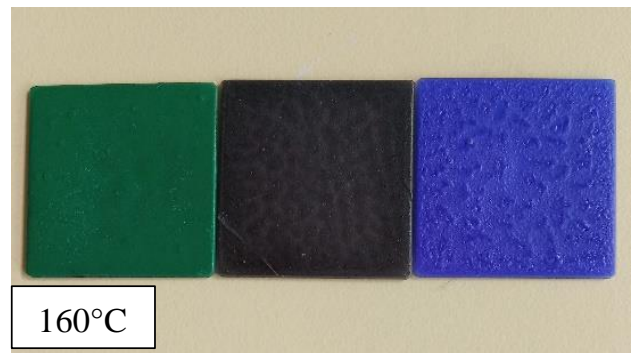

Şekil 13. Yapılışından 30 ay geçen $160^{\circ} \mathrm{C}$ 'de 1 sıl işlem sıcaklığına tabi tutulmuş kaplamalar $\left(25^{\circ} \mathrm{C} / \mathrm{dk}\right.$. 1sıtma hızında $30 \mathrm{dk}$. bekleme süresinde)
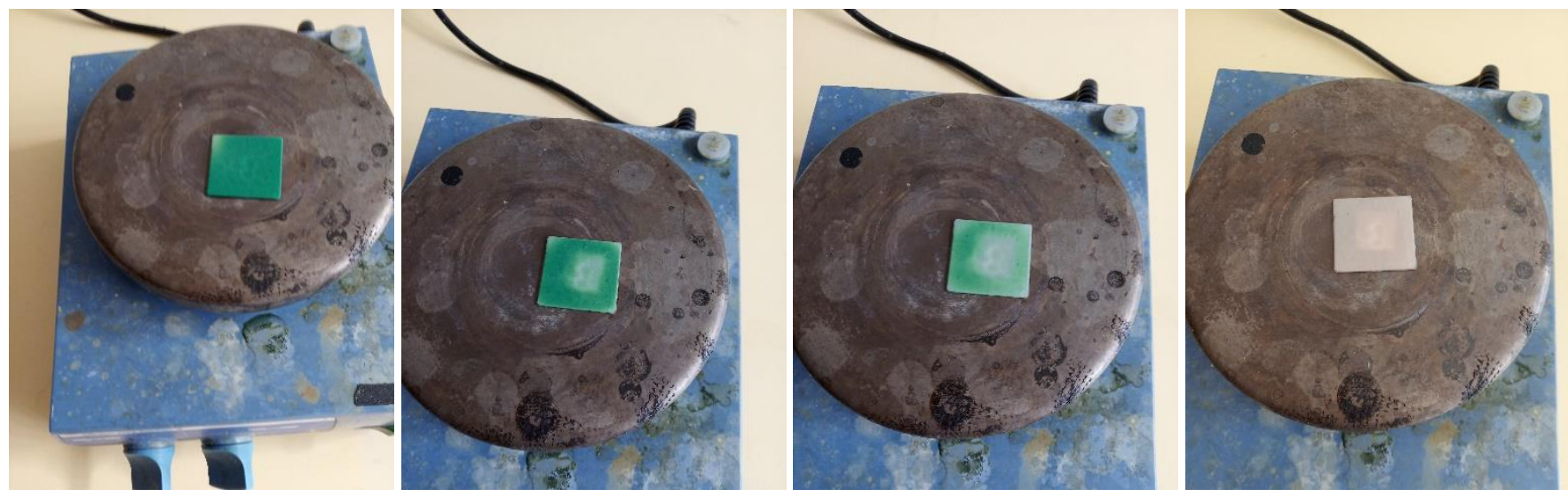

Şekil 14. 30 ay sonra 1sitırken yeşil renk numunenin renk değişimi
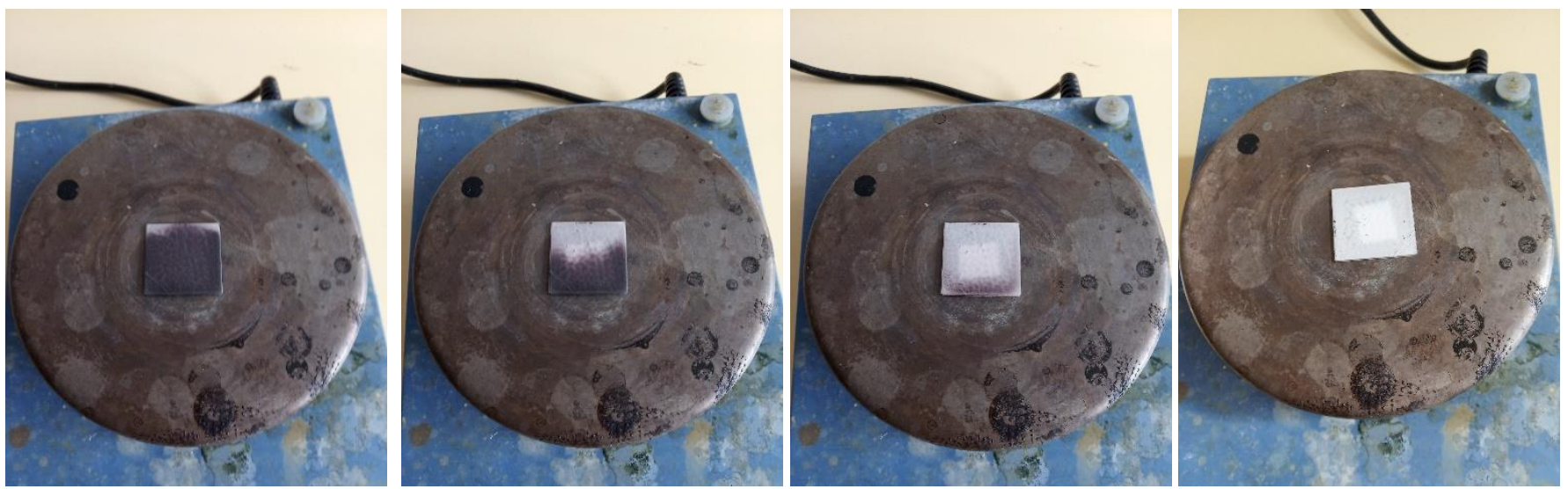

Şekil 15. 30 ay sonra 1sıtırken siyah renk numunenin renk değiş̧imi 

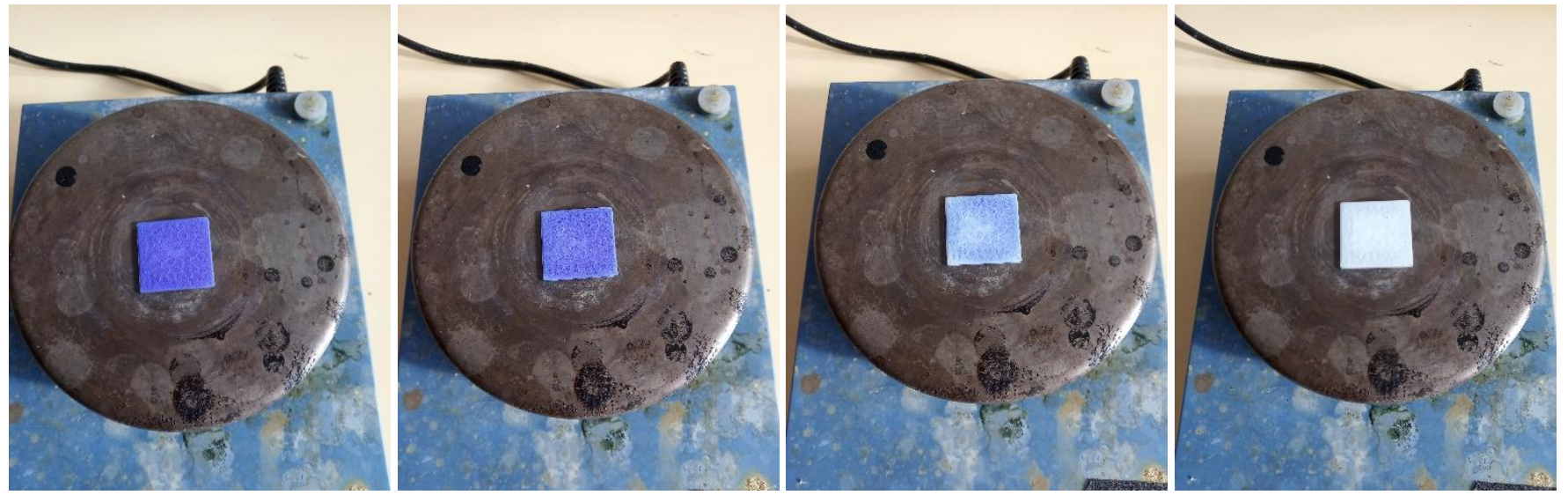

Şekil 16. 30 ay sonra ısıtırken mavi renk numunenin renk değişim
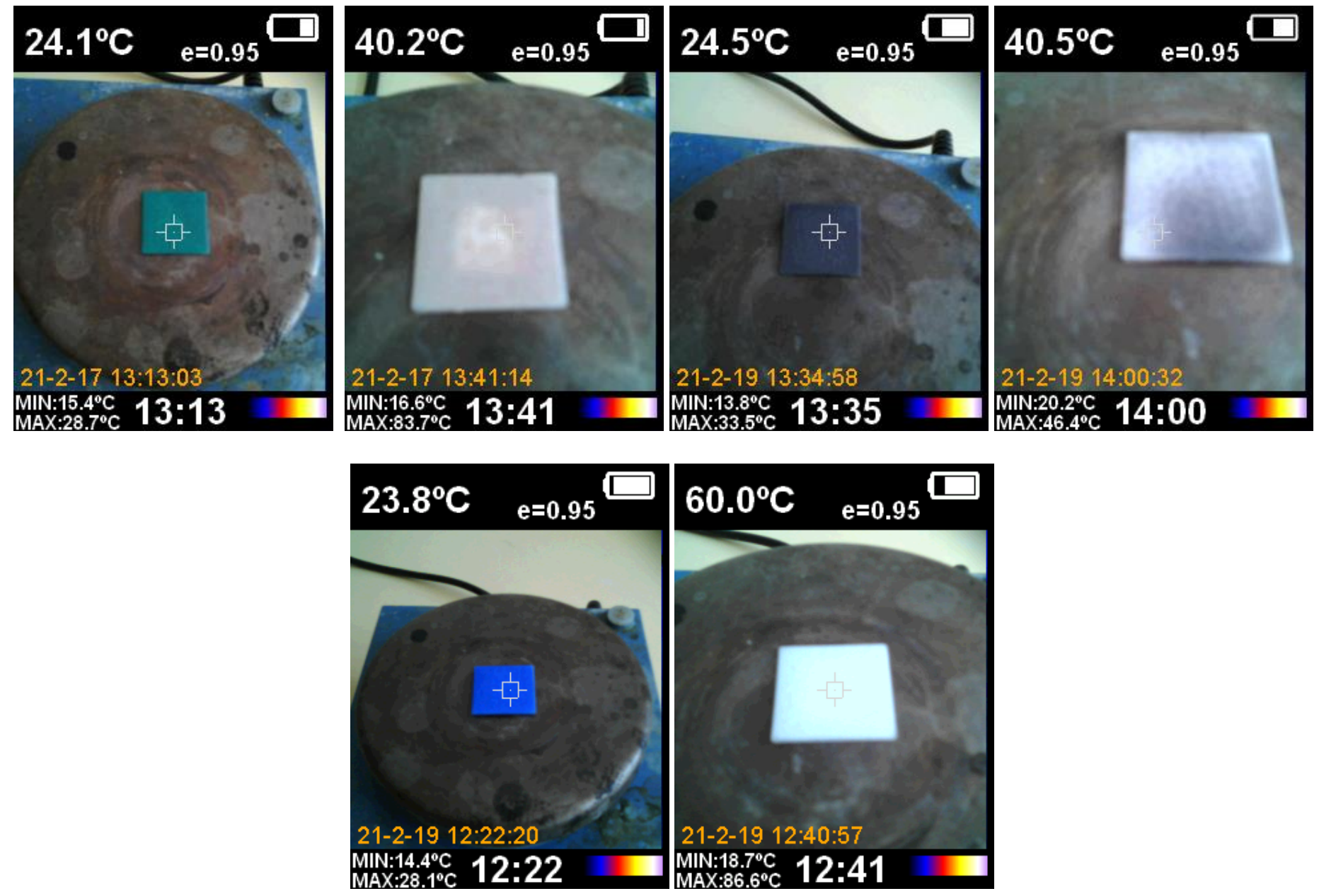

Şekil 17. $160^{\circ} \mathrm{C}$ 'de 1 sıl işlem sıcaklığına tabi tutulmuş yeşil, siyah ve mavi kaplamaların kızılötesi termal kamera ile incelenmesi

\subsection{SEM Analizleri}

Şarjlanma olmadan iletkenliği sağlamak için belirli süre altın kaplama yapılan numuneler Zeiss marka Supra 50 VP model SEM kullanılarak mikroyapı analizleri gerçekleştirilmiştir. Şekil 18-20, 1sıl işlem sonrası termokromik kaplamaların morfolojik değişimlerini göstermektedir. Isıl işlem sıcaklığ $180^{\circ} \mathrm{C}$ olan yeşil, siyah ve mavi kaplamalarda çatlakların oluştuğu gözlemlenmiştir. Ayrıca kuvars lamellerin kaplanan yüzeyinde gaz çıkışı olduğundan kabarcıklar oluşmuştur. $180^{\circ} \mathrm{C}$ 'de $30 \mathrm{dk}$. 1sıl işlem gören numunelerin yüzeyindeki gaz çıkışı artarak krater görünümlü yüzeylere neden olmuştur. Oluşturulan tüm kaplamaların mikro yapısında pigment mikrokapsülleriyle ilişkili küresel yapılar veya küre parçaları bulunmaktadır. Öte yandan, küresel yapılar, kaplamaların içinde homojen yayılma sergilemiştir. 

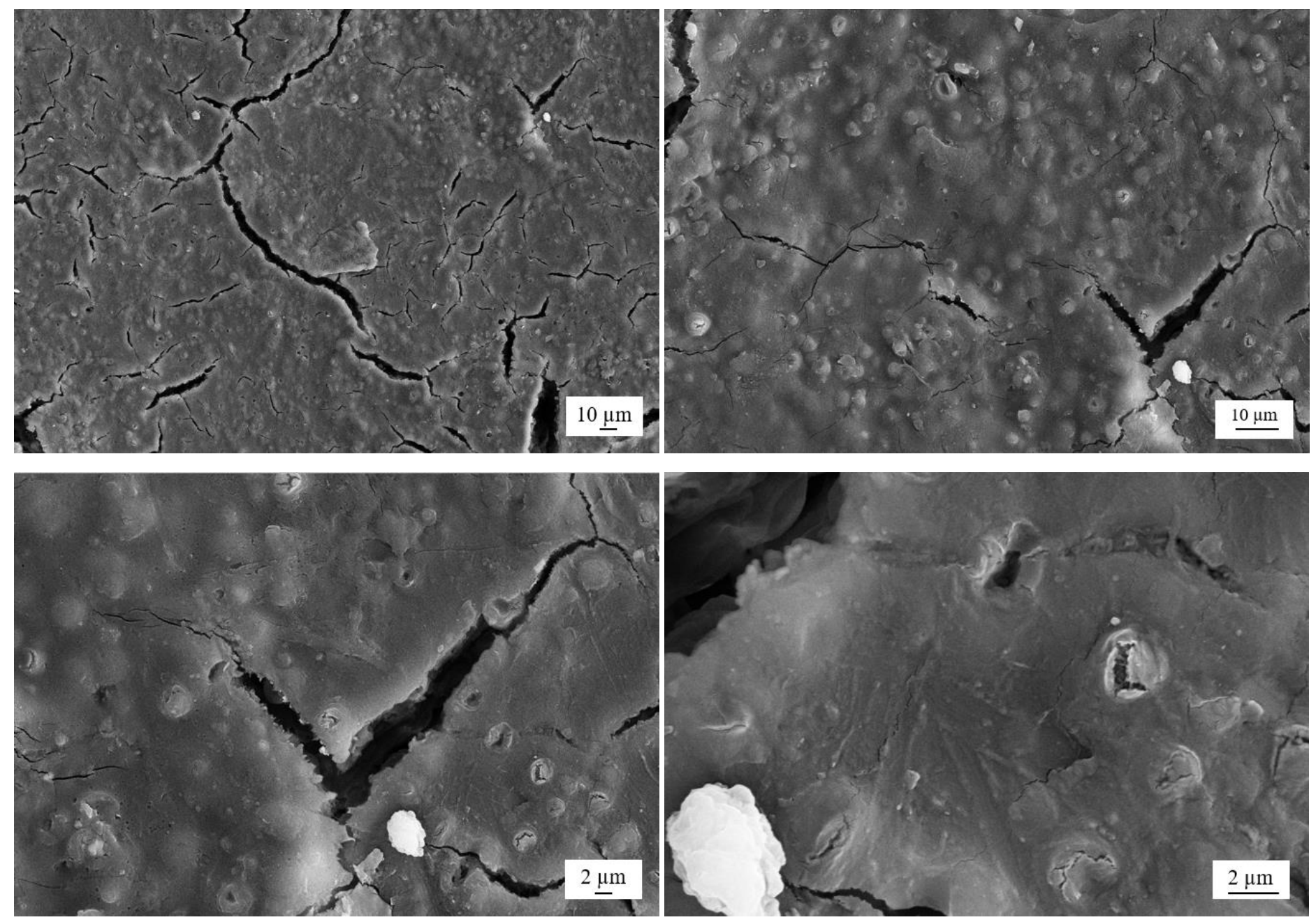

Şekil 18. $180^{\circ} \mathrm{C}$ 'de $30 \mathrm{dk}$. 1 sıl işlem sonrasında yeşil pigmentli termokromik kaplamaların SEM görüntüleri
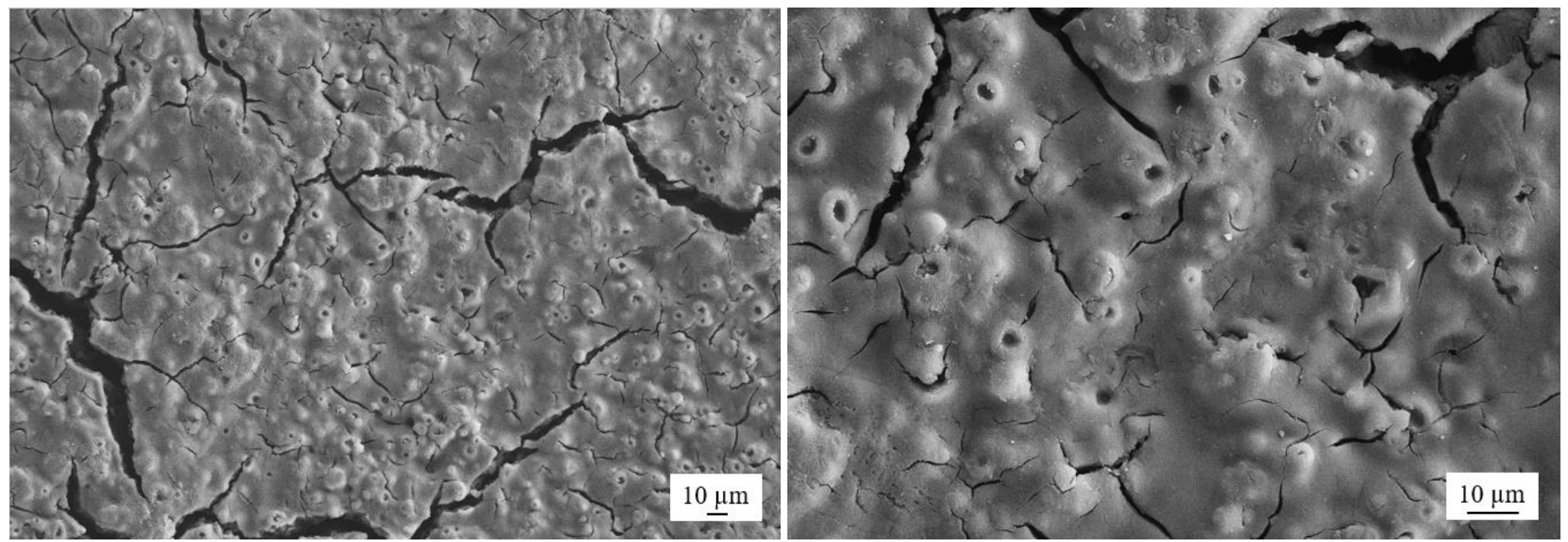

Şekil 19. $180^{\circ} \mathrm{C}^{\prime}$ de $30 \mathrm{dk}$. 1 sıl işlem sonrasında siyah pigmentli termokromik kaplamaların SEM görüntüleri 

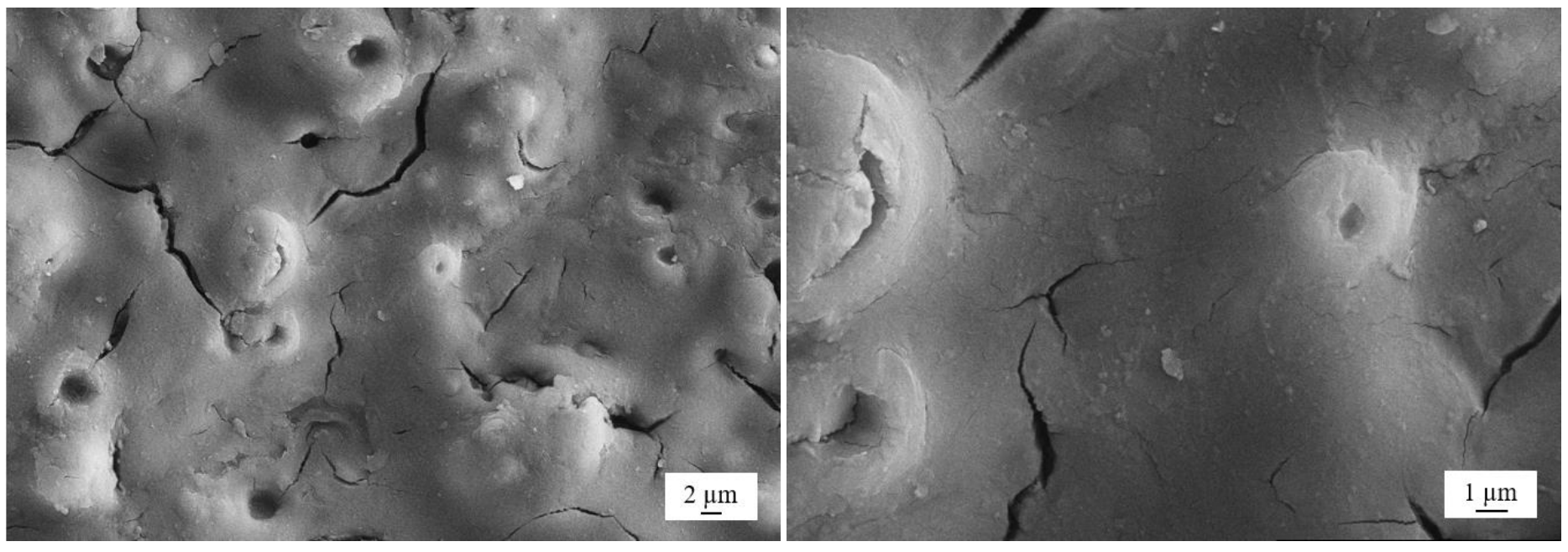

Şekil 19 (devam). $180^{\circ} \mathrm{C}^{\prime}$ de $30 \mathrm{dk}$. 1 sıl işlem sonrasında siyah pigmentli termokromik kaplamaların SEM görüntüleri
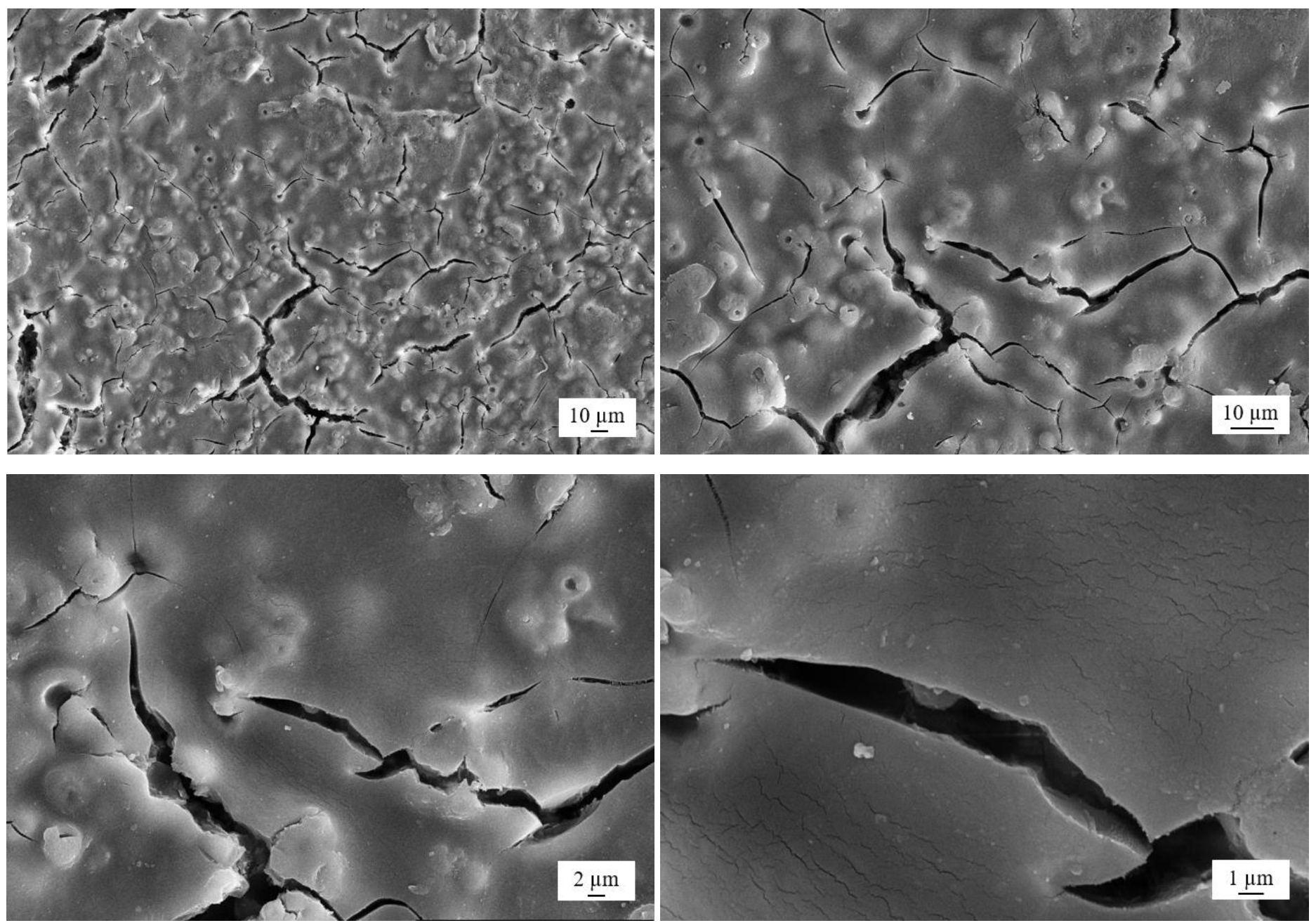

Şekil 20. $180^{\circ} \mathrm{C}$ 'de $30 \mathrm{dk}$. 1 sıl işlem sonrasında mavi pigmentli termokromik kaplamaların SEM görüntüleri

\subsection{EDX Analizleri}

Enerji saçınımlı X-ışını (EDX) cihazı kullanılarak termokromik kaplamaların elementel analizleri tespit edilmiştir. $180^{\circ} \mathrm{C}$ 'de 1 ssıl işleme tabi tutulduktan sonra termokromik kaplamaların üzerindeki elementlerin EDX görüntüleri Şekil 21-24'te gösterilmektedir. Yalıtkan numunelere, SEM karakterizasyonundan önce altın paladyum kaplama yapıldığı için, spektruma Au ve Pd pikleri de dahil edilmiştir. Enerji yayılımlı X-Işını analizleri (EDX) kaplamaların ana bileşimini ortaya koymaktadır. EDX analitik bir teknik olup, 
karakterizasyon X-ışını uyarımı kaynağın ve numunenin etkileşimine dayanır. Alınan görüntüde spektrum 1 olarak belirlenmiş bölüme EDX analizi yapılmıştır. Şekil 21(a)'da gösterilen EDX ile yapılan elementel analiz sonucunda \% 28,05 C, \% 3,64 N, \% 0,15 Na, \% $0,13 \mathrm{Cl}, \%$ 0,66 Pd, \% 0,57 Au ve \% 66,79 O belirlenmiştir. Numunenin spektrum 2 olarak belirlenmiş bölüme yapılan elementel analizinde \% 28,19 C, \% 3,85 N, \% 0,48 Pd, \% 0,39 Au ve \% 67,08 O olarak tespit edilmiştir (Şekil 21(b)).
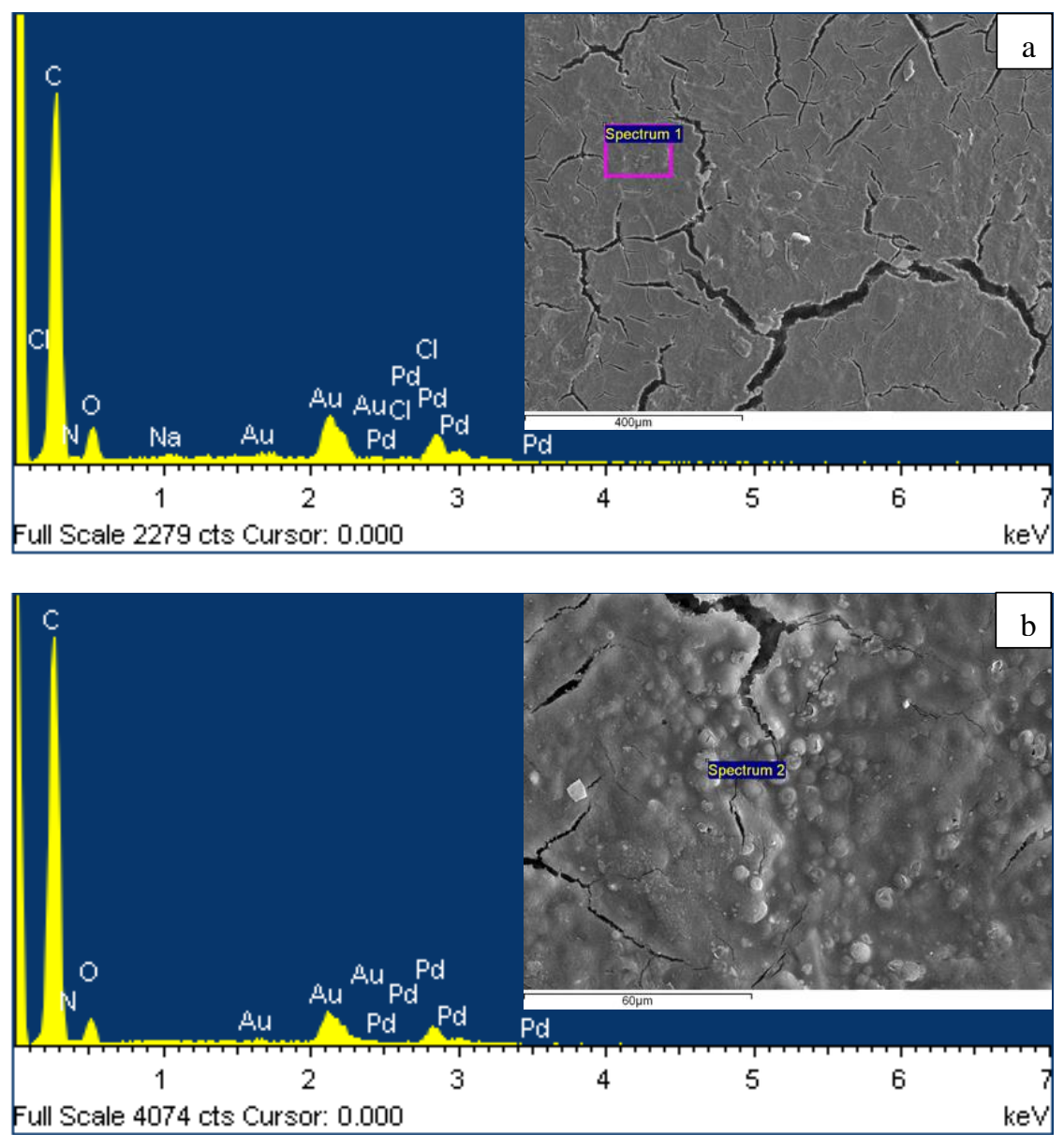

Şekil 21. (a) $180^{\circ} \mathrm{C}$ 'de $30 \mathrm{dk}$. ısıl işlem gören yeşil kaplamanın spektrum 1 olarak belirlenmiş bölüme yapılan EDX analizi (b) Spektrum 2 olarak belirlenmiş bölüme yapılan EDX analizi

Elde edilen görüntüde Spektrum 4 olarak belirlenmiş bölüme yapılan EDX analizinde \% 25,87 C, \% 5,30 N, \% 0,97 Pd, \% 0,75 Au, \% 67,10 O belirlenmiştir (Şekil 22).

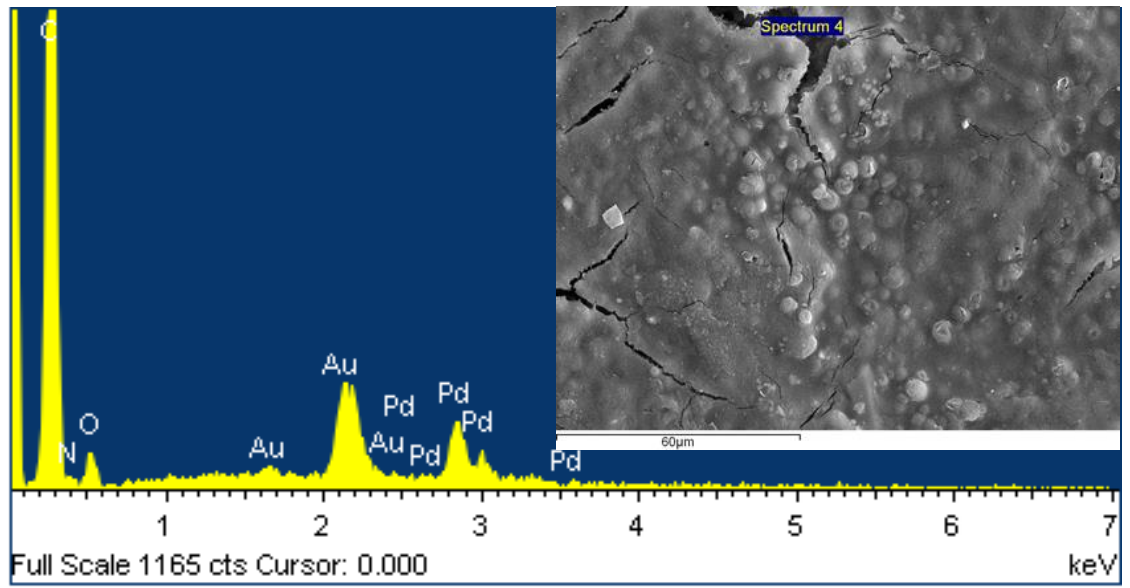

Şekil 22. $180^{\circ} \mathrm{C}^{\prime}$ de $30 \mathrm{dk}$. 1 sıl işlem gören yeşil kaplamanın spektrum 4 olarak belirlenmiş bölüme yapılan EDX analizi 
Mavi ve siyah kaplamalarda yapılan EDX analizleri incelemeleri sonucunda bor oksit $\left(\mathrm{B}_{2} \mathrm{O}_{3}\right)$ varlığ tespit edilmiştir. Şekil 23(a)'da alınan görüntüde pembe dikdörtgen olarak belirlenmiş bölüme yapılan EDX analizinde \% 6,51 B, \% 24,31 C, \% 2,72 N, \% 0,28 Pd, \% $0,28 \mathrm{Au}, \%$ 65,90 O belirlenmiştir. Spektrum 6 olarak belirlenmiş bölüme yapılan EDX analizinde \% 7,65 B, \% 23,41 C, \% 2,68 N, \% 0,30 Pd, \% 0,26 Au, \% 65,69 O belirlenmiştir (Şekil 23(b)).
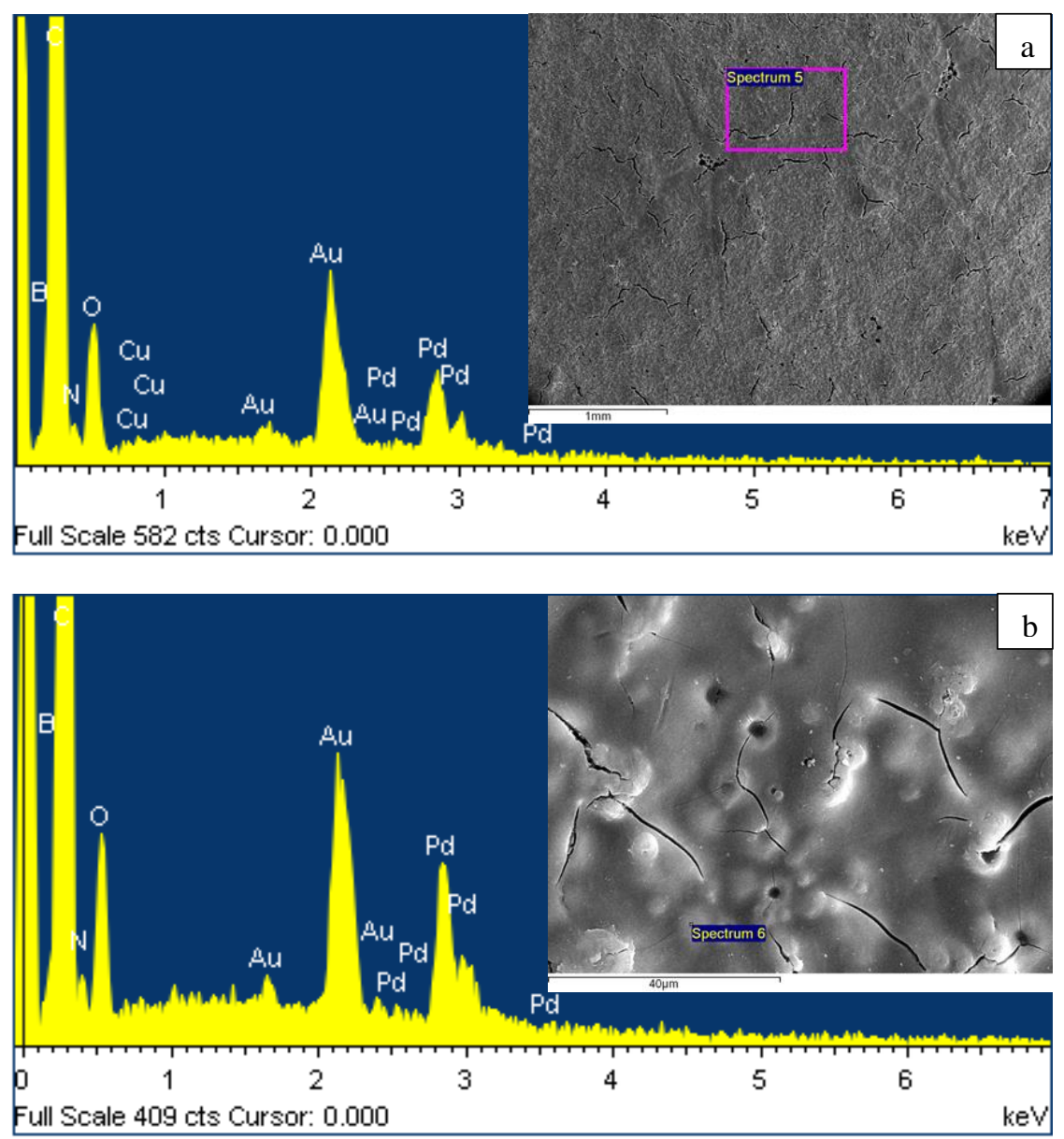

Şekil 23. (a) $180^{\circ} \mathrm{C}^{\prime}$ de $30 \mathrm{dk}$. $1 \mathrm{~s} 1$ işlem gören mavi kaplamanın spektrum 5 olarak belirlenmiş bölüme yapılan EDX analizi (b) Spektrum 6 olarak belirlenmiş bölüme yapılan EDX analizi

Şekil 24'deki Spektrum 9 olarak belirtilen bölgenin EDX analizinde \% 7,07 B, \% 23,69 C, \% 2,71 N, \% 0,42 Pd, \% 0,37 Au, \% 65,74 $\mathrm{O}$ tespit edilmiştir. Siyah kaplamaya yapılan diğer bir EDX analizinde \% 7,38 B, \% 22,76 C, \% 3,26 N, \% 0,48 Pd, \% 0,37 Au, \% $65,76 \mathrm{O}$ belirlenmiştir. Oluşturulan tüm kaplamalar esas olarak karbon ve oksijenden oluşur ve bu da organik bileşik yapısını işaret eder.

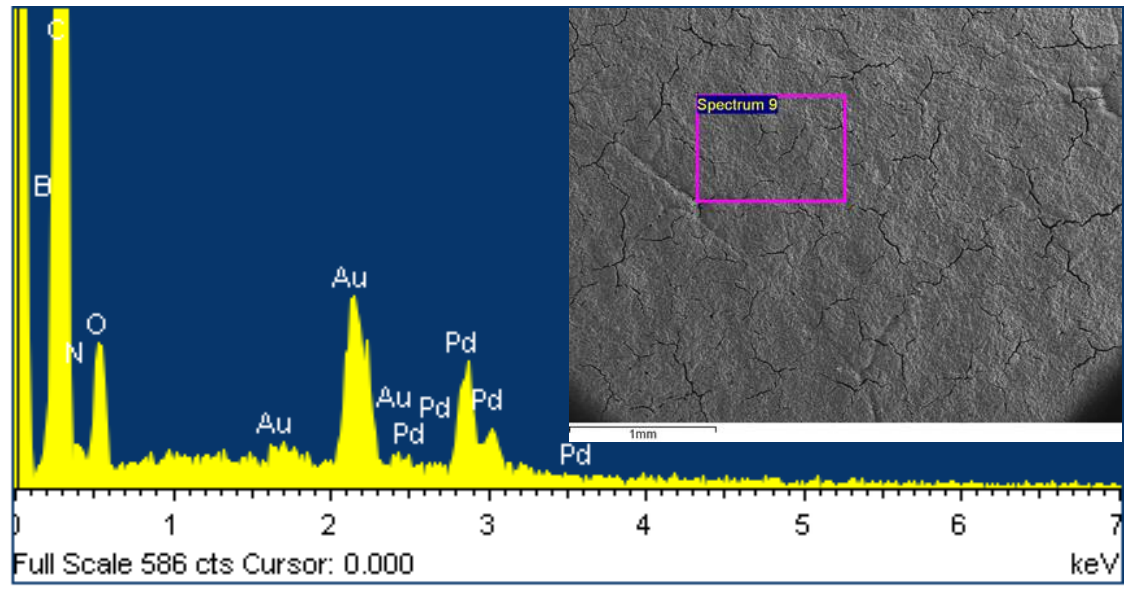

Şekil 24. $180^{\circ} \mathrm{C}$ 'de $30 \mathrm{dk}$. 1sıl işlem gören siyah kaplamanın spektrum 9 olarak belirlenmiş bölüme yapılan EDX analizi 


\section{Tartışma ve Sonuç}

Termokromik kaplamalar, binalar ve çevre arasında akıllı etkileşim sağlayabilir ve kentsel termal ortamı iyileştirebilir. Termokromik malzemeler, hem ssitma hem de soğutma dönemlerinde bina enerji tüketimini azaltma potansiyeline sahiptir. Termokromik kaplamalar temel olarak görünür banttaki yansıma değişsimiyle güneş radyasyonunun soğurma kabiliyetini düzenler (Zhang \& Zhai, 2019). Bu çalışmada organik mikrokapsüllenmiş termokromik pigmentlere dayalı akıllı tersinir termokromik kaplamalar sunulmuştur. Sıcaklıkla tersine değişen optik özelliklere sahip kapsüllenmiş tersinir termokromik pigmentler oluşturulan kaplamalarda kullanılmıştır. Burada oluşturulan kompozisyonda termokromik pigmentlere 1sıyla çapraz bağlanabilen polivinilpirolidon ve çözücü olarak 2-propanol dahil edilmiştir. Sıcaklığa göre yeşil, siyah, mavi ile beyaz arasında renk değiştiren akıllı kaplama elde etmek için kuvars lamel üzerine rakle ile kaplama uygulanmıştır. Termokromik kaplamaların renklendirme ve beyaz renge dönme etkisi araştırılmıştır. Termokromik pigmentlerle oluşturulan kaplamaların XRD, SEM-EDX, renk analizleri yapılmış renk değişim sıcaklıkları tespit edilmiştir. Yeşil, siyah ve mavi olmak üzere üç farklı renkteki kaplamalar uygun bir bağlayıcı sisteme termokromik pigmentler eklenerek oluşturulmuştur. Oluşturulan kaplamalar yeşilden beyaza beyazdan yeşile, siyahtan beyaza beyazdan siyaha, maviden beyaza beyazdan maviye tersinir şekilde renk değişikliği göstermektedir. Polivinilpirolidonun eklenmesi kaplama kalınlığını arttırmıştır. Mikro yapı çalışmalarında oluşturulan tüm kaplamalarda çatlak ve krater görünümlü yapılar belirlenmiştir. İyi dağılmış termokromik pigmentlere sahip kaplamaların rengi, sıcaklık değişimine hızlı tepki göstermiştir ve bu da tek tip renk dönüşümüyle sonuçlanmıştır. Sonuç olarak oluşturulan tüm kaplamalar geri dönüşümlü renk tersinirliği sergilemiştir. Geliştirilen bukalemun tipi bina kaplamaları, enerji tüketimi sorunlarını çözmek, termal olarak rahat bir ortam oluşturmak amacıyla bina iç dekorasyon malzemesi olarak kullanılabilir. Bu akıllı tersinir termokromik kaplamanın geliştirilmesinde gelecekteki çalışmalar, dış bina kaplaması olarak uygulanmasıyla ilgili dayanıklılık sorunlarına yönelik olmalıdır.

\section{Referanslar}

Aklujkar, P. S., \& Kandasubramanian, B. (2020). A review of microencapsulated thermochromic coatings for sustainable building applications. Journal of Coatings Technology and Research, 1-19. doi:org/10.1007/s11998-020-00396-3

Berardi, U., Garai, M., \& Morselli, T. (2020). Preparation and assessment of the potential energy savings of thermochromic and cool coatings considering inter-building effects. Solar Energy, 209, 493-504. doi:org/10.1016/j.solener.2020.09.015

Calovi, M., Russo, F., \& Rossi, S. (2021). Synergic behavior of graphene-based filler and thermochromic pigments in cataphoretic coatings. Progress in Organic Coatings, 150, 105978. doi:org/10.1016/j.porgcoat.2020.105978

Chen, Y.-Y., \& Wei, W.-C. J. (2001). Formation of mullite thin film via a sol-gel process with polyvinylpyrrolidone additive. Journal of the European Ceramic Society, 21(14), 2535-2540. doi:org/10.1016/S0955-2219(01)00277-1

Cheng, Y., Zhang, X., Fang, C., Chen, J., \& Wang, Z. (2018). Discoloration mechanism, structures and recent applications of thermochromic materials via different methods: A review. Journal of Materials Science \& Technology, 34(12), $2225-2234$. doi:org/10.1016/j.jmst.2018.05.016

Ferrara, M., \& Bengisu, M. (2014). Materials that change color: smart materials, intelligent design (pp. 9-60). Springer. doi: 10.1007/978-3-319-00290-3

Garshasbi, S., \& Santamouris, M. (2019). Using advanced thermochromic technologies in the built environment: Recent development and potential to decrease the energy consumption and fight urban overheating. Solar Energy Materials and Solar Cells, 191, 21-32. doi:org/10.1016/j.solmat.2018.10.023

Hu, J., \& Yu, X. B. (2019). Adaptive thermochromic roof system: Assessment of performance under different climates. Energy and Buildings, 192, 1-14. doi:org/10.1016/j.enbuild.2019.02.040

$\mathrm{Hu}$, J., \& Yu, X. B. (2020). Adaptive building roof by coupling thermochromic material and phase change material: Energy performance under different climate conditions. Construction and Building Materials, 262 , 120481. doi:org/10.1016/j.conbuildmat.2020.120481

Karlessi, T., \& Santamouris, M. (2015). Improving the performance of thermochromic coatings with the use of UV and optical filters tested under accelerated aging conditions. International Journal of Low-Carbon Technologies, 10(1), 45-61. doi:org/10.1093/ijlct/ctt027

Karlessi, T., Santamouris, M., Apostolakis, K., Synnefa, A., \& Livada, I. (2009). Development and testing of thermochromic coatings for buildings and urban structures. Solar Energy, 83(4), 538-551. doi:org/10.1016/j.solener.2008.10.005 
Kuźmińska, A., Butruk-Raszeja, B. A., Stefanowska, A., \& Ciach, T. (2020). Polyvinylpyrrolidone (PVP) hydrogel coating for cylindrical polyurethane scaffolds. Colloids and Surfaces B: Biointerfaces, 192, 111066. doi:org/10.1016/j.colsurfb.2020.111066

Pedaballi, S., Li, C.-C., \& Song, Y.-J. (2019). Dispersion of microcapsules for the improved thermochromic performance of smart coatings. RSC advances, 9(42), 24175-24183. doi: 10.1039/c9ra04740a

Pérez, G., Allegro, V. R., Corroto, M., Pons, A., \& Guerrero, A. (2018). Smart reversible thermochromic mortar for improvement of energy efficiency in buildings. Construction and Building Materials, 186, 884-891. doi:org/10.1016/j.conbuildmat.2018.07.246

Pérez, G., Mota-Heredia, C., Sánchez-García, J., \& Guerrero, A. (2020). Compatibility between thermochromic pigments and Portland cement-based materials. Construction and Building Materials, 251, 119038. doi:org/10.1016/j.conbuildmat.2020.119038

Rajadurai, R. S., Lee, J.-H., Choi, E., \& Kang, J.-W. (2020). MnNH4P2O7-Based Coating for High Temperature Assessment on the Surfaces of Cement Composites. Coatings, 10(4), 396. doi:org/10.3390/coatings10040396

Rossi, S., Simeoni, M., \& Quaranta, A. (2021). Behavior of chromogenic pigments and influence of binder in organic smart coatings. Dyes and Pigments, 184, 108879. doi:org/10.1016/j.dyepig.2020.108879

Santamouris, M., Synnefa, A., \& Karlessi, T. (2011). Using advanced cool materials in the urban built environment to mitigate heat islands and improve thermal comfort conditions. Solar Energy, 85(12), 3085-3102. doi:org/10.1016/j.solener.2010.12.023

Štaffová, M., Kučera, F., Tocháček, J., Dzik, P., Ondreáš, F., \& Jančář, J. (2021). Insight into color change of reversible thermochromic systems and their incorporation into textile coating. Journal of Applied Polymer Science, 138(4), 49724. doi:org/10.1002/app.49724

Yan, X., Chang, Y., \& Qian, X. (2019). Effect of the concentration of pigment slurry on the film performances of waterborne wood coatings. Coatings, 9(10), 635. doi:org/10.3390/coatings9100635

Yan, X., Wang, L., \& Qian, X. (2020). Effect of coating process on performance of reversible thermochromic waterborne coatings for Chinese fir. Coatings, 10(3), 223. doi:org/10.3390/coatings10030223

Yuxuan, Z., Yunyun, Z., Jianrong, Y., \& Xiaoqiang, Z. (2020). Energy saving performance of thermochromic coatings with different colors for buildings. Energy and Buildings, 215, 109920. doi:org/10.1016/j.enbuild.2020.109920

Zhang, H., Chen, Z., Li, L., \& Zhu, C. (2017). Evaluation of aging behaviors of asphalt with different thermochromic powders. Construction and Building Materials, 155, 1198-1205. doi:org/10.1016/j.conbuildmat.2017.08.161

Zhang, Y., \& Zhai, X. (2019). Preparation and testing of thermochromic coatings for buildings. Solar Energy, 191, 540-548. doi:org/10.1016/j.solener.2019.09.042 